\title{
Retinal Dysfunction in Alzheimer's Disease and Implications for Biomarkers
}

\author{
Chunyan Liao ${ }^{1,2}$, Jinying $X u^{1,2,3}$, Yu Chen ${ }^{1,2,3, *}$ and Nancy Y. Ip ${ }^{2,4, *}$ \\ 1 Chinese Academy of Sciences Key Laboratory of Brain Connectome and Manipulation, Shenzhen Key \\ Laboratory of Translational Research for Brain Diseases, The Brain Cognition and Brain Disease Institute, \\ Shenzhen Institute of Advanced Technology, Chinese Academy of Sciences, Shenzhen-Hong Kong Institute of \\ Brain Science-Shenzhen Fundamental Research Institutions, Shenzhen 518055, China; \\ cy.liao@siat.ac.cn (C.L.); jy.xu@siat.ac.cn (J.X.) \\ 2 Guangdong Provincial Key Laboratory of Brain Science, Disease and Drug Development, Shenzhen-Hong \\ Kong Institute of Brain Science, HKUST Shenzhen Research Institute, Shenzhen 518057, China \\ 3 Shenzhen College of Advanced Technology, University of Chinese Academy of Sciences, \\ Beijing 100049, China \\ 4 Division of Life Science, Molecular Neuroscience Center, and State Key Laboratory of Molecular \\ Neuroscience, The Hong Kong University of Science and Technology, Hong Kong 999077, China \\ * Correspondence: yu.chen@siat.ac.cn (Y.C.); boip@ust.hk (N.Y.I.); \\ Tel.: +86-755-2692-5498 (Y.C.); +852-2358-6161 (N.Y.I.)
}

Citation: Liao, C.; Xu, J.; Chen, Y.; Ip, N.Y. Retinal Dysfunction in Alzheimer's Disease and Implications for Biomarkers. Biomolecules 2021, 11, 1215. https://doi.org/10.3390/ biom11081215

Academic Editors: Sara Merlo,

Dmitry Lim and Simona

Federica Spampinato

Received: 2 July 2021

Accepted: 9 August 2021

Published: 16 August 2021

Publisher's Note: MDPI stays neutral with regard to jurisdictional claims in published maps and institutional affiliations.

Copyright: (c) 2021 by the authors. Licensee MDPI, Basel, Switzerland. This article is an open access article distributed under the terms and conditions of the Creative Commons Attribution (CC BY) license (https:// creativecommons.org/licenses/by/ $4.0 /)$.

\begin{abstract}
Alzheimer's disease (AD) is a progressive neurodegenerative disorder that manifests as cognitive deficits and memory decline, especially in old age. Several biomarkers have been developed to monitor $\mathrm{AD}$ progression. Given that the retina and brain share some similarities including features related to anatomical composition and neurological functions, the retina is closely associated with the progression of AD. Herein, we review the evidence of retinal dysfunction in AD, particularly at the early stage, together with the underlying molecular mechanisms. Furthermore, we compared the retinal pathologies of $\mathrm{AD}$ and other ophthalmological diseases and summarized potential retinal biomarkers measurable by existing technologies for detecting $\mathrm{AD}$, providing insights for the future development of diagnostic tools.
\end{abstract}

Keywords: Alzheimer's disease; retinal abnormality; biomarker; amyloid-beta; tau; vascular changes

\section{Introduction}

Alzheimer's disease (AD), the most prevalent form of dementia, is a progressive neurodegenerative disorder that features a decline in memory and defects in cognitive functions. The pathological hallmarks of AD include the deposition of extracellular amyloidbeta $(A \beta)$ plaques and the formation of neurofibrillary tangles by the intracellular hyperphosphorylated tau protein [1]. Over the past few decades, there has been significant progress in understanding AD pathophysiology and in the development of intervention strategies. Nevertheless, there is still no effective treatment or adequate diagnostic tools for AD. Pathological changes caused by AD can emerge several years or even decades before neurodegeneration and cognitive impairment occur, making it extremely challenging to implement effective interventions once these clinical symptoms become severe [2]. Therefore, biomarkers for $\mathrm{AD}$ are urgently required for the early diagnosis and risk prediction of the disease.

Notably, the presence of retinal aberrations in AD, including $A \beta$ deposition, neurofibrillary tangle aggregation, abnormal retinal microvascular circulation, and thinning of the retinal nerve fiber layer (RNFL), suggests the intriguing possibility of developing easily measurable retinal biomarkers for early-stage AD diagnosis [3]. Herein, we review the current knowledge of retinal dysfunction in AD and the development of potential biomarkers based on such retinal abnormalities. We also discuss the pathophysiology and related biomarkers for AD that overlap with other ophthalmological diseases. 


\section{Retinal Changes in Alzheimer's Disease and Implications for Biomarkers}

As the incidence of $\mathrm{AD}$ increases worldwide, largely due to global population aging, enormous efforts have been made to develop effective approaches for screening highrisk individuals before $\mathrm{AD}$ symptoms occur or identifying patients with $\mathrm{AD}$ at early stages. For example, various methods have been used to detect neurotoxic $A \beta_{42}$ and $A \beta_{40}$, phosphorylated tau, total tau, and neurofilament light chain in cerebrospinal fluid (CSF) and plasma; changes in the absolute quantities or ratios of these biomarkers are strongly associated with $\mathrm{AD}$ progression [4,5]. In addition, positron emission tomography (PET) is used to visualize $A \beta$ and tau deposition or measure the metabolic rate in the brains of patients, while magnetic resonance imaging (MRI) is used to detect brain atrophy $[6,7]$. However, these methods have limited utility for population-level screening owing to high cost, invasiveness, or ineffectiveness in discerning changes in early-stage AD or identifying high-risk individuals.

The eyes are the primary visual sensory organs. The retina comprises the neural retina and retinal pigment epithelium (RPE) and is a crucial component of the central nervous system [8]. The neural retina develops from the neural tube and is enriched with neurons including retinal ganglion cells (RGCs), photoreceptor cells, bipolar cells, amacrine cells, and horizontal cells $[8,9]$. In addition, three main types of glia cells support retinal homeostasis: Müller glial cells, astrocytes, and microglia [10]. The neural retina comprises three cellular layers including the ganglion cell layer (GCL), inner nuclear layer (INL), and outer nuclear layer (ONL). The ONL is covered with rod and cone photoreceptors, which transmit visual information to RGCs located in the GCL via interneurons within the INL. The neurons of the INL, which include bipolar, horizontal, and amacrine cells, process and transduce signals to the ganglion cells. Meanwhile, the synaptic junctions in the retina congregate in the outer plexiform layer (OPL) and inner plexiform layer (IPL). The OPL covers the synapses between the photoreceptors and INL cells including horizontal and bipolar cells. The IPL is occupied by synapses between the INL cells and RGCs. Thus, visual signals are transmitted from the RGCs to the brain via the optic nerve [11].

Therefore, the retina is considered an extension of the brain as well as a potential source of AD biomarkers that can be evaluated noninvasively [12,13]. Accordingly, retinal biomarkers have been identified for the early screening of individuals at high risk of AD $[14,15]$. Nevertheless, the mechanisms underlying the RGC and the optic nerve degeneration involved in visual abnormalities in $\mathrm{AD}$ are not well understood. $\mathrm{A} \beta$ deposition in the retina is neurotoxic and potentially fatal to RGCs, resulting in RNFL thinning and optic nerve degeneration. Meanwhile, retinal cell functioning can be disrupted by defects in neurotransmitters such as acetylcholine [16-18].

\subsection{Structural Degeneration of the Retina in Early-Stage Alzheimer's Disease}

Structural abnormalities of the retina in AD include optic nerve degeneration, neuronal loss, and reduced thickness of the RNFL and other retinal layers. In 1986, Hinton et al. found that patients with AD showed broad axonal degeneration in the optic nerve, which was verified by $p$-phenylenediamine staining [19]. They subsequently reported RGC degeneration in patients with $\mathrm{AD}$, which featured cell swelling, nuclear disintegration, and a vacuolated cytoplasm [20]. A meta-analysis of optical coherence tomography (OCT) data found that the RNFL was significantly thinner in patients with mild cognitive impairment (MCI) or AD than in healthy people [21]; the loss of RGCs and optic nerve axons may be accounted for by the RNFL thinning [22,23]. Other studies have confirmed this finding [24-26], further indicating that such anomalous retinal alterations might appear in early-stage AD.

Blanks et al. quantified the neurons in different retinal regions in $\mathrm{AD}$ cases and controls, and found that the former had fewer GCL neurons in the central retina (i.e., 3-mm diameter region) [27]. In particular, the GCL neurons in the fovea (0-0.5-mm eccentricity) exhibited the largest reduction in $\mathrm{AD}$ cases compared to that in controls; there were also smaller reductions in the numbers of neurons with the eccentricity of $0.5-1$ - and 
1-1.5-mm in AD cases [27]. Blanks et al. subsequently found that neuronal losses were most dramatic in the superior and inferior quadrants in AD cases compared to those in healthy controls [28].

The macula, approximately $6 \mathrm{~mm}$ in diameter, contains the highest concentration of RGCs, whose degeneration is implicated in AD. Neuronal loss in the macular ganglion cell-inner plexiform layer (GC-IPL) is closely associated with patients with MCI or AD, but not cognitively normal controls; macular GC-IPL neuronal loss is associated with MCI more strongly than axonal loss in the RNFL [29]. Nevertheless, another study reported a significant reduction in GCL thickness in all retinal quadrants (i.e., superior, inferior, temporal, and nasal) in patients with $\mathrm{AD}$ or $\mathrm{MCI}$ compared to age-matched healthy controls; however, the IPL was remarkably reduced in all retinal quadrants in AD, but not in MCI [30]. Meanwhile, the macular ganglion cell complex (GCC), which contains the three innermost layers of the retina (i.e., the RNFL, GCL, and IPL), was significantly reduced in patients with AD compared to healthy controls, although no significant difference in outer retinal layer thickness was observed between groups [31,32].

However, several studies observed no differences in retina parameters between patients with $\mathrm{AD}$ and healthy controls, which is contradictory to the abovementioned data. One study showed that the $A \beta$ positive and $A \beta$ negative groups had no statistically significant differences in terms of macular retinal layer thickness and peripapillary RNFL thickness [33]. This apparent discrepancy may arise from the different diagnostic criteria used in these studies or the different disease stages of the AD participants [33]. On the other hand, whether subjects with ophthalmological diseases such as age-related macular degeneration (AMD) and glaucoma are excluded will also affect the statistical results of AD-associated retinal changes [33]. Another study also found no significant differences in RNFL and GCL thickness between patients with AD and controls, owing to the lack of amyloid imaging for accurate diagnosis and limited cohort size [34]. Improvement of diagnosis consistency across cohorts and the use of more specific biomarkers may help solve the discrepancy.

Structural changes of the retina can be detected by comprehensive imaging techniques. For example, various ophthalmological disorders are clinically assessed and diagnosed using spectral-domain OCT, an improved noninvasive method providing two-dimensional, crosssectional pictures of the morphological structures of the retina at high resolution, as well as three-dimensional volumetric parameters such as RNFL thickness, macular thickness, and macular volume [35-37]. This technological development has enabled the observation of the optic nerve topography, RNFL thickness, and macular volume, which are potential clinical biomarkers for early-stage AD diagnosis [13,31,38,39]. Given that the macula includes approximately half of all RGCs and the GC-IPL represents the distribution of RGC bodies and dendrites [40], the finding that macular GC-IPL thickness rather than RNFL thickness is more closely associated with $\mathrm{MCI}$ indicates that RGC neuronal loss might start in the macular region [29]. Therefore, macular GC-IPL thinning might be a sensitive indicator of the early changes that occur in the retina in AD [29,41]. However, OCT imaging lacks the specificity to distinguish $\mathrm{AD}$ from other degenerative disorders that share retinal layer thinning (e.g., AMD and glaucoma) or optic nerve impairment (e.g., glaucoma). Therefore, further investigation of $\mathrm{AD}$-specific impacts on particular retinal regions is required to improve the feasibility of using OCT-based biomarkers for early AD diagnosis.

\subsection{Electrophysiological Changes of the Retina in Early-Stage Alzheimer's Disease}

Besides structural changes of the retina in $\mathrm{AD}$, emerging evidence suggests that functional changes of the electrophysiological properties in specific retinal regions and visual impairment are associated with $\mathrm{AD}[42,43]$. The noninvasive pattern electroretinogram (PERG) and pattern visual evoked potential (PVEP) tests reveal the bioelectrical functions of the retina and optic nerve [17]. In response to stimulation, the standard transient PERG recording wave includes three peaks: negative, positive, and negative polarity waves appear at approximately $35 \mathrm{~ms}$ (N35), $50 \mathrm{~ms}$ (P50), and $95 \mathrm{~ms}$ (N95), respectively [44]. The 
PERG response mirrors the electrical activity of the central retinal and ganglion cells and can contribute to auxiliary diagnoses for various anterior visual pathway diseases [44-48]. Furthermore, the amplitude and peak latency of PVEP are associated with the number of functional optic nerve fibers, which can be used as an objective assessment of visual pathway connectivity $[49,50]$. In PVEP testing, the recording wave also contains 3 peaks at $75 \mathrm{~ms}$ (N75), $100 \mathrm{~ms}$ (P100), and $135 \mathrm{~ms}$ (N135); P100 mirrors the functional bioelectricity in the optic nerve [18,51]. Moreover, retinocortical time-the latency difference between the PERG positive wave (i.e., P50) and the PVEP positive wave (i.e., P100)—provides more-exact information concerning the visual pathway transmission in the retina $[17,50,52]$. Several studies show that the PERG and PVEP parameters are altered in patients with AD at the early stage, which is consistent with the occurrence of RGC degeneration and optic nerve dysfunction $[17,18,53-56]$. For example, compared to healthy controls, patients with mild AD showed increased implicit time of the P50 wave and decreased amplitudes of both the P50 and N95 waves, suggesting that RGC and optic nerve dysfunction occur in early-stage AD [17]. Meanwhile, compared to healthy controls, patients with early-stage AD showed significantly longer P100-wave latency in the PVEP test and significantly longer retinocortical time, indicating dysfunctions of the optic nerve and neural conduction in the postretinal visual pathway [17]. These results suggest that key PERG and PVEP parameters are potential $\mathrm{AD}$ biomarkers.

\subsection{Amyloid-Beta Deposition in the Retina in Alzheimer's Disease}

$\mathrm{A} \beta$ plaque deposition in the brain is a key feature of $\mathrm{AD}$ pathology and a potential biomarker for AD diagnosis [57]. A $\beta$ is produced from APP ( $\beta$-amyloid precursor protein) processing via $\beta$-secretase and $\gamma$-secretase cleavage [58]. During APP processing, the expression and activity of the $\beta$-secretase enzyme BACE1 ( $\beta$-site APP-cleaving enzyme 1 ) is critical in A $\beta$ production [58]. In APP/PS1 transgenic mice (a transgenic mouse model of AD), obvious BACE1 expression is detected in the GCL of the retina at 3 months, spreading to the IPL and OPL at 6 and 8 months, respectively; meanwhile, only weak BACE1 expression is observed in wild-type mice at 6 and 8 months [59]. Furthermore, enhanced BACE1 expression in various brain areas such as the entorhinal cortex, hippocampus, and prefrontal cortex is observed in APP/PS1 mice at 6 and 8 months, which is much later than when altered BACE1 expression appears in the retina (Table 1). This suggests that retinal BACE1 abnormalities are an early pathological feature and a potential biomarker of $\mathrm{AD}[59]$.

Table 1. Sequential occurrence of amyloid-beta deposition and BACE1 appearance in the retina and the brain in Alzheimer's disease.

\begin{tabular}{|c|c|c|}
\hline $\begin{array}{l}\text { Molecular } \\
\text { Changes }\end{array}$ & Retina & Brain \\
\hline $\begin{array}{c}\mathrm{A} \beta \\
\text { deposition }\end{array}$ & $\begin{array}{l}\text { In the retina at } 2.5 \text { months in APP/PS1 mice [60] } \\
\text { In the GCL of the retina at } 5-10 \text { post-natal weeks in 3xTg-AD mice [61] } \\
\text { Senile plaque appeared in the retina at } 2 \text { months in 5xFAD mice and at } 6 \\
\text { months in PSAPP mice [62] } \\
\text { Soluble A } \beta_{42} \text { appeared at } 3 \text { months in APPN-G-F knock-in mice [63] } \\
\text { In the GCL, RNFL, OPL, ONL, INL, and IPL of the retina in patients } \\
\text { with AD [64,65] and in the whole-mounted retinas of patients with } \\
\text { definite AD or suspected early-stage AD [60] }\end{array}$ & $\begin{array}{l}\text { Appears at } 5 \text { months in APP /PS1 mice [60] } \\
\text { Distributes in the neocortex, entorhinal region, } \\
\text { hippocampus, diencephalic, brain stem, and cerebellar } \\
\text { regions of the brain in patients with AD [66] }\end{array}$ \\
\hline $\begin{array}{l}\text { BACE1 } \\
\text { expression }\end{array}$ & $\begin{array}{l}\text { In the GCL of the retina at } 3 \text { months and then spreads to the IPL and } \\
\text { OPL at } 6 \text { and } 8 \text { months, respectively, in APP/PS1 mice [59] }\end{array}$ & $\begin{array}{l}\text { In the entorhinal cortex, hippocampus, and prefrontal } \\
\text { cortex at } 6 \text { and } 8 \text { months in APP/PS1 mice [59] } \\
\text { Increased expression of BACE1 in the temporal cortex } \\
\text { and hippocampus in the AD brain }[67,68] \\
\text { High activity of BACE1 in the brain in patients with } \\
\text { sporadic AD [67] } \\
\text { High activity of BACE1 in the cerebrospinal fluid in } \\
\text { patients with MCI or AD [69] }\end{array}$ \\
\hline
\end{tabular}

$\mathrm{A} \beta$, amyloid-beta; AD, Alzheimer's disease; BACE1, $\beta$-site APP-cleaving enzyme 1; GCL, ganglion cell layer; INL, inner nuclear layer; IPL, inner plexiform layer; MCI, mild cognitive impairment; ONL, outer nuclear layer; OPL, outer plexiform layer; RNFL, retinal nerve fiber layer. 
$\mathrm{A} \beta$ burden results in a series of AD-related pathological cascades including synaptic dysfunction, neuronal inflammation, oxidative stress, neuronal apoptosis, and damage to the mitochondria and endoplasmic reticulum, which ultimately lead to neuronal loss in the brain and cognitive impairment [61,70-73]. Moreover, $A \beta$ induces neurotoxicity and impairs the functions of various cells such as neurons, astrocytes, microglia, and vascular endothelial cells [74]. Electron microscopy of RGCs in the Tg2576 AD mouse model reveals significantly altered mitochondrial complexity accompanied by mitochondrial swelling with large inter-mitochondrial spaces and fragmented cristae, which may be caused by A $\beta$ accumulation [41]. Meanwhile, one recent study investigating the proteins and signaling pathways affected by $A \beta$ administration in retinal photoreceptor cells found that $A \beta$ causes ribosomal dysfunction, cytoskeletal protein dysregulation, and oxidative phosphorylation alterations [75]. Furthermore, $A \beta$ might induce neurodegeneration concomitant with elevated immunoreactivity of MCP-1-, F4/80-, and TUNEL-positive cells in the retinal GCL, indicating increased inflammation and cell apoptosis [76].

Interestingly, several studies have documented $\mathrm{A} \beta$ accumulation in various retinal layers including the GCL, RNFL, OPL, ONL, INL, and IPL in cases of definite AD (Table 1) $[64,65]$. One study analyzed the retinal plaques in patients with $\mathrm{AD}$ on flat mounts and cross-sections using anti-A $\beta$ antibodies (i.e., 12F4, 6E10, 4G8, and 11A5-B10) or compounds (i.e., curcumin and Congo red). The results showed all patients with AD had higher levels of $\mathrm{A} \beta$ deposition than controls [65]. Flat mounts analysis revealed that in $\mathrm{AD}$ retinas, $A \beta$ is mainly distributed in the middle and far periphery of the superior quadrants, consistent with the observed neuronal loss and RNFL thinning of the superior retina [65]. Furthermore, staining of $A \beta$ deposits in cross-sections from the superior retina shows that A $\beta$ mainly accumulates in the innermost retinal layers (i.e., the GCL, INL, IPL, and ONL), especially in the GCL nearby or inside vascular walls [65]. Another study reported clusters of $\mathrm{A} \beta$ deposits in whole-mounted postmortem retinas of both patients with definite $\mathrm{AD}$ and those with suspected early-stage $\mathrm{AD}$, whereas no $\mathrm{A} \beta$ plaques were observed in controls [60]. This suggests that retinal $A \beta$ plaques can occur several years before the clinical signs of AD appear.

Consistent with findings from patients with $\mathrm{AD}$, retinal plaques have also been reported in pre-symptomatic 3xTg-AD [61], Tg2576 [62,77], PSAPP [62], APP/PS1 [60,76,78,79], and 5xFAD mouse models of $\mathrm{AD}[62,80]$ and in the APP ${ }^{\mathrm{NL}-\mathrm{G}-\mathrm{F}}$ knock-in mouse model [63]. For example, in APP/PS1 mice, both APP and A $\beta$ deposition were detected in the retina including the RNFL, GCL, IPL, OPL, and INL (Table 1) $[60,76,78,79]$. More interestingly, in APP/PS1 mice, retinal A $\beta$ plaques can be found as early as 2.5 months while brain plaques first appear at 5 months, indicating that retinal $A \beta$ plaques emerge before brain plaques [60].

From a wholistic perspective, the presence of retinal $A \beta$ plaques in AD remains controversial. While many studies report retinal $A \beta$ plaques in animal models of $A D$ or human patients, other studies report no $A \beta$ plaques in the retinas of patients with definite AD [20,81-83], or APP/PS1 or Tg2576 mice [81]. This inconsistency may be due to differences in retinal regions, variable expression of retinal pathology among patients with $\mathrm{AD}$, or differences in technologies or detection conditions such as $\mathrm{A} \beta$ immunofluorescent antibodies and chemical compounds [82,83].

PET imaging is a minimally invasive method that detects $A \beta$ plaques and is therefore important for the clinical diagnosis of $\mathrm{AD}$, although inaccessibility and cost hinder its population-scale application [84]. To detect $A \beta$ oligomers, several researchers have attempted to exploit antibodies (e.g., 12F4, 6E10, 4G8, and 11A5-B10) and chemicals that bind to $\mathrm{A} \beta$ (e.g., curcumin, thioflavin, and Congo red). In particular, curcumin, a natural fluorescent compound with a high affinity for the $\beta$-pleated sheet structure of $A \beta$ along with its oligomers, fibrils, and plaques, can pass through the blood-brain and blood-retina barriers after systemic administration $[60,85,86]$. In addition, clinical trials of curcumin have confirmed its low toxicity and safety, even at high dosages [87]. Retinal imaging technologies are used to visualize retinal $A \beta$ plaques after curcumin administration in vivo. Curcumin staining is also used to examine postmortem retinas. Thus, curcumin specifically 
labels the retinal $\mathrm{A} \beta$ plaques, providing a noninvasive and feasible strategy for detecting early AD [60].

Prompted by a lack of methods to directly determine and quantify A $\beta$ aggregates or fibrils, hyperspectral imaging (HSI) was developed to obtain spectral and spatial information about the retina by examining retinal $\mathrm{A} \beta$ without extrinsic fluorescent labeling (which binds $A \beta$ ), but rather through scanning within a certain wavelength range (i.e., visible to near-infrared) $[84,88]$. Thus, HSI spectral signatures can delineate the structural and biochemical variations of tissues, providing physiological, morphological, and histological diagnostic information for clinical applications [89]. Multiple studies using HSI have helped construct a database illustrating the spectral signature of $A \beta$ aggregates [88,90]. Furthermore, the $A \beta$ signature is associated with the order and kinetics of neuron-damaging $A \beta$ aggregation, but not with monomeric or insoluble $A \beta$ [90]. Upon using the DROPD (Dimension Reduction by Orthogonal Projection for Discrimination) spectral analysis method to correct for inherent spectral variability, AD cases and controls exhibited different spectra according to the spectral data of $A \beta$ in solution [84]. HSI analysis can identify $A \beta$-containing assemblies within the retina, specifically soluble $A \beta$ aggregates in patients with $\mathrm{AD}$, and thus generate the spectral signatures that discriminate patients with $\mathrm{AD}$ from healthy controls $[84,88]$. Interestingly, changes in the retinal HSI signature are much more dramatic in $\mathrm{MCI}$ cohorts than in $\mathrm{AD}$ cohorts with moderate cognitive impairment, suggesting that using HSI to detect retinal $A \beta$ is a promising biomarker for early-stage AD [90]. Importantly, the retinal HSI signature is affected by structural alterations and biochemical variations such as hyperphosphorylated tau protein, iron accumulation, and inflammation; however, it is unaffected by other ophthalmological disorders including cataracts and glaucoma and is minimally affected upon aging [90,91]. Therefore, the development of HSI-based retinal biomarkers is a promising and sensitive method for large-scale preclinical AD risk screening.

\subsection{Hyperphosphorylated Tau Aggregation}

The pathological aggregation of hyperphosphorylated tau protein, which forms neurofibrillary tangles, is strongly correlated with cognitive decline in AD [92-94]. Hyperphosphorylated tau dissociates from microtubules, resulting in the destabilization of the microtubules and aberrations in neuronal functions [95]. Levels of hyperphosphorylated tau protein in the CSF and tau aggregation shown in brain PET imaging are considered biomarkers for clinical AD diagnosis [93,96].

Tau and its hyperphosphorylated forms have been detected in the retinas of patients with $\mathrm{AD}$ [3]. One study that assessed postmortem retinas in AD cases showed that total tau protein (detected by the HT7 antibody) is distributed in the retinal IPL and OPL, which are enriched with axonal connections [83]. Importantly, hyperphosphorylated tau with different phospho-epitopes (i.e., AT8, AT100, and AT270) is elevated in the OPL and IPL in patients with $\mathrm{AD}$ compared to that in controls [83]. Hyperphosphorylated tau protein immunoreactivity (i.e., AT8) is especially more obvious in the superior retina than the mid-retina and is distributed in a gradient increasing toward the periphery [83].

Consistent with these findings in humans, an accumulation of hyperphosphorylated tau aggregates is observed in AD mouse models [77,97-99]. For example, early retinal tau accumulation has been found in 3-month-old 3xTg-AD mice, preceding the occurrence of cognitive defects and tau aggregates in the brain [99]. Of note, retinal tau is distributed in the dendrites, soma, and intraretinal axons of RGCs, but is markedly decreased in the optic nerve axons in 3xTg-AD mice, suggesting that in early-stage $\mathrm{AD}$, tau accumulation is lower in RGC axons within the optic nerve [99]. Retinal tau accumulation in early-stage $\mathrm{AD}$ can lead to neuronal impairment. Anterograde transport from RGCs to the superior colliculus in the brain is significantly higher in 3-month-old 3xTg-AD mice treated with tautargeting siRNA, suggesting that the reduction of retinal tau partially restores RGC axonal transport [99]. Another study indicates that tau hyperphosphorylation (i.e., at Thr231, Thr205, or Ser396) is elevated in the retina in APP/PS1 transgenic mice [100]. Interestingly, 
this increased hyperphosphorylated tau in the retina of APP/PS1 transgenic mice is related to the upregulation of $\mathrm{p} 35 / \mathrm{p} 25$ and activation of Cdk5 (cyclin-dependent kinase 5), which is mediated by calpain [100]. Furthermore, oligomeric tau is observed in the retina of tauopathy mice (i.e., P301L tau transgenic mice) and patients with AD or frontotemporal lobar dementia and is colocalized with Iba1-labeled microglia, GFAP-labeled astrocytes, and the pro-inflammatory cytokine HMGB1; these findings suggest that tau aggregates are associated with retinal inflammation [101]. Concordantly, neurofibrillary tangle levels are remarkably elevated in APP/PS1 mice compared to controls [100]. Nevertheless, the changes of neurofibrillary tangles in the retina remain controversial, as some studies report a lack of fibrillary tau, paired helical filaments, or neurofibrillary tangles in $\mathrm{AD}$ or tauopathies $[81,83]$. In addition, tau abnormality is also detected in glaucoma, which shares some characteristics with $\mathrm{AD}$, such as optic nerve degeneration and visual pathway impairment [102].

In summary, hyperphosphorylated tau aggregates in the retina and is implicated in the pathogenesis of AD-related phenotypes, suggesting that retinal tau is a potential biomarker for early-stage AD. Schön et al. detected fibrillary tau aggregates by using scanning laser ophthalmoscopy after systemic administration of FSB ([E,E]-1-fluoro-2,5bis [3-hydroxycarbonyl-4-hydroxy]styrylbenzene) to label the cells containing fibrillary tau and found that FSB-positive RGCs increased in the retina of P301S transgenic mice in vivo [81]. However, effective applications for detecting retinal tau in patients with $A D$ are currently unavailable.

\subsection{Blood Vessels and Retinal Microcirculation}

Cerebrovascular disease might lead to cognitive impairment and dementia in elderly patients [103]. In fact, there are some overlapping symptoms between AD and cerebrovascular disease. Furthermore, many patients with AD also have cerebrovascular disease, vascular pathology, or moderate-to-severe cerebral amyloid angiopathy, as shown in the National Alzheimer's Coordinating Centre Minimum Data Set [104]. Neuropathological studies show that large numbers of patients with vascular dementia have AD pathological characteristics [105], making it a challenge to distinguish between AD and mixed dementia in clinical settings. Interestingly, vascular impairments such as cerebral vascular infarction, arteriolar and venous stenosis, cerebral microbleeds, and capillary density reduction are key etiological factors involved in the development of early-stage AD [106]. Therefore, if vascular changes are established in $\mathrm{AD}$ cases, they can potentially be used as diagnostic criteria for $\mathrm{AD}[3]$.

The cerebral and retinal vasculatures have similar developmental origins, anatomical characteristics, and functional features, and retinal vascular abnormalities also occur in AD $[107,108]$. Accumulating evidence indicates that various retinal vascular parameters (RVPs) are related with AD-associated changes. Recent studies suggest that emerging retinal vascular alterations might mirror the cerebrovascular pathophysiological processes in $\mathrm{AD}[3,107,109]$. For example, in a case-control study, the retinas of patients with mildto-moderate probable AD (including those with mild or moderate dementia) exhibited obvious shrinkage of the venous blood column diameter and decreased venous blood flow rate compared to controls [23]. Furthermore, a recent study analyzed the retinal microvascular network of healthy subjects, patients with $\mathrm{MCI}$, and patients with AD by quantitative analysis of the foveal avascular zone area and examination of the densities of the superficial retinal capillary plexuses (SRCPs) and deep retinal capillary plexuses (DRCPs) [110]. The results showed that the density of retinal microvasculature decreased in the DRCPs in all parafoveal and perifoveal quadrants in patients with $\mathrm{AD}$; moreover, microvascular density was significantly reduced in most parafoveal quadrants (i.e., superior, temporal, and nasal) of the internal annular zone and in the superior external annular zone of the perifovea in the DRCPs in patients with MCI compared to healthy controls [110]. This suggests that retinal microvascular density in the DRCPs is a promising biomarker for early-stage AD. Another study reported that compared to controls, patients with AD have narrower venular 
calibers, reduced arteriolar and venular fractal dimensions, and increased tortuosity of arterioles and venules [107]. Consistently, the tortuosity of the retinal venules and arterioles is remarkably higher in $\mathrm{A} \beta$-positive individuals than $\mathrm{A} \beta$-negative individuals [111], corroborating the correlation between retinal vascular tortuosity and AD pathology. However, in one study, retinal imaging revealed decreased arteriolar tortuosity in patients with $\mathrm{AD}$ compared to controls [109]; this discrepancy might be due to other factors influencing the vascular tortuous process-for example, genetic differences, changes in vascular wall properties, or degenerative vascular disease [109]. Frost et al. examined RVPs in heathy subjects with high or low brain amyloid (the high brain amyloid group represents individuals in the preclinical stage of $\mathrm{AD}$ ) and found that venule asymmetry factor and arteriole length diameter ratio were higher in the high brain amyloid group [112]. These findings indicate that RVPs changes are involved in the early stage of AD pathogenesis. Meanwhile, the study showed that a logistic model combining RVPs provides more accurate classification for the $\mathrm{AD}$ group than a logistic model combining age and AopE4 carrier status [112]. Thus, these RVPs (to a certain extent) are potential biomarkers for AD.

Most patients with $A D$ exhibit comorbid cerebral amyloid angiopathy featuring $A \beta$ in cerebral vessels [113], suggesting that cerebrovascular $A \beta$ accumulation is associated with both AD and cerebral amyloid angiopathy pathology [114-116]. Pericytes and vascular cells control the blood flow of capillaries and maintain blood-brain barrier permeability, which is important for $\mathrm{A} \beta$ clearance in the brain $[117,118]$. The neural retina has a similar vasculature and blood barrier containing endothelial cells, pericytes, and astrocytes. Patients with $\mathrm{AD}$, but not healthy controls, exhibit $\mathrm{A} \beta$ deposition within the vasculature and pericytes accompanied by pericyte loss [119]. In particular, PDGFR $\beta$ (platelet-derived growth factor receptor- $\beta$ ) in the vertical vessels of postmortem retinas is significantly lower in patients with $\mathrm{MCI}$ or $\mathrm{AD}$ than in cognitively normal controls and is correlated with increased in retinal vascular $A \beta_{40}$ and $A \beta_{42}$ in MCI and $A D$ [119]. These findings imply that the blood-retina barrier mediates the retinal vascular disruption involved in $\mathrm{AD}$ and that retinal vascular parameters (e.g., vascular $A \beta$ and PDGFR $\beta$ signaling) might be early signs of the occurrence of $\mathrm{AD}$. Nevertheless, damage to the blood-retina barrier, which regulates retinal metabolism and vascular leakage, is a crucial factor in other retinal microvascular disorders such as AMD [120], diabetic macular edema [121], diabetic retinopathy [122], and uveitis [123]. Therefore, retinal vascular disruption may be nonspecific for AD detection.

Contrary to reduced density of deep vascular plexus (DVP) being reported in patients with MCI or AD, some studies found no significant difference in DVP between patients with AD and cognitively normal controls [110,124,125]. Many factors including type 2 diabetes mellitus, the detection equipment being used, and differing neurocognitive assessments may explain these contradictory results [124]. To overcome the variations caused by manual measurement and analysis, an automated modular machine learning pipeline that includes image quality selection, vessel map segmentation, and final classifier was recently developed to achieve AD classification based on the retinal vasculature changes [126]. In this way, the proposed pipeline could differentiate patients with AD from healthy controls efficiently and with high accuracy; meanwhile, the generated saliency map showed the small blood vessel was more important for classifying $\mathrm{AD}$, which is consistent with previous studies showing the vessel features of AD progression [126-128].

Certain technologies have been used to examine vascular alterations in the retina in patients with $\mathrm{AD}$. Retinal photography, a routine method for examining the retina, can reveal qualitative vascular signs including variation in the retinal vascular caliber, global geometrical patterns, and retinopathy [129]. A software that can quantitatively measure RVPs such as tortuosity and caliber provides a more effective evaluation of the vascular changes [130]. Of note, $\mathrm{AD}$ shares some common retinal changes with other diseases, including variations in vessel caliber (e.g., in AMD, stroke, diabetic retinopathy, and atherosclerosis), limiting the application of single retinal photographs for AD screening $[13,131]$. Nevertheless, advanced longitudinal parameters of retinal alterations based on retinal photography could improve the accuracy of identifying early-stage AD. 
Furthermore, early microvascular abnormalities in AD might be identified using OCT-angiography followed by software-based quantification of the microvascular density of the retinal zone [132]. Moreover, various ophthalmological diseases can be assessed using Doppler OCT and laser Doppler blood flowmeter, which measure retinal blood flow [133]. One study showed that retinal venous blood flow assessed by laser Doppler blood flowmeter is significantly lower in patients with AD or MCI than in healthy controls [134]. Consistent with these findings, a Doppler OCT study showed that retinal arterial and venous blood flow are significantly reduced in patients with $\mathrm{AD}$ or $\mathrm{MCI}$ compared to controls [135]. Given that the tortuosity of the retinal arterioles and venules as well as the diameter and textures of vessels are altered in $\mathrm{AD}$, combining these vascular features and spatial-spectral texture data from different retinal regions by hyperspectral retinal imaging can facilitate the classification accuracy between $A \beta$-positive and $A \beta$-negative groups [111].

\subsection{Apoptosis in the Retina in Alzheimer's Disease}

Besides the various retinal changes reported in $\mathrm{AD}$, corresponding molecular pathways are implicated in AD pathogenesis. Given that the $A \beta$ accumulation is observed in several retinal layers in $A D, A \beta$ may be associated with RGC death in $A D, A M D$, and glaucoma [136]. A $\beta$ peptides exhibit toxicity toward neurons and glia and can result in apoptosis associated with neuronal loss in AD [137,138]. Accordingly, cell death markers can be used to trace apoptotic cells within the retina in vivo. New imaging techniques involving labeling with ANX776 (annexin 5 labeled with fluorochrome DY-776), Zn-DPA (bis[zinc\{II\}]-dipicolylamine), and other fluorescent dyes can monitor apoptotic cells [139-141]. For example, Zn-DPA can bind to the phosphatidylserine that is exposed to cell membranes during early-stage apoptosis and be detected by fluorescence imaging after intravitreal injection [141]. Another study showed that retinal cell apoptosis could be monitored in mice and rats by fluorescence imaging using Zn-DPA conjugated with Texas red (PSVue-550) administered noninvasively by eye drops [140]. ANX776 has been verified as safe with no adverse effects in humans after intravenous injection and has a short half-life of 10-36 min [139]. Intravenous injection of ANX776 combined with DARC (detection of apoptosing retinal cells) imaging can allow to visualization of retinal cell apoptosis (as spots labeled by ANX776) in real time in vivo for glaucoma and other neurodegenerative disorders such as AD and Parkinson's disease [139]. These findings suggest that this technology can help monitor early-stage retinal apoptosis in vivo.

\section{Alzheimer's Disease and Other Retinal Diseases}

Aberrant retinal changes in AD are potential novel biomarkers for early-stage AD. Of note, several ophthalmological disorders including AMD and glaucoma may partially overlap with $\mathrm{AD}$ owing to their shared characteristics such as neuron degeneration, $\mathrm{A} \beta$ deposition, and microvascular abnormalities [142,143].

\subsection{Retinal Dysfunction in Age-Related Macular Degeneration}

AMD is a common retinal degenerative disease in the elderly population [144]. Earlystage AMD features the emergence of drusen and RPE degeneration, while late-stage AMD features geographic atrophy and choroidal neovascularization [144]. Some studies suggest that AMD and AD might be comorbid by showing that patients with AMD have an increased risk of AD [145-147], although this correlation becomes not significant when considering other factors such as age, presence of the apolipoprotein E (ApoE) allele, smoking, and atherosclerosis $[145,148]$. Evidence that $A \beta$ deposition is involved in chronic inflammation, oxidative stress, and neuronal damage in both AD and AMD, suggests that the pathological similarities between these diseases, to some extent, may reduce the specificity of potential biomarkers for AD diagnosis [149].

Investigations of the pathological features of $A D$ and $A M D$ reveals several retinarelated parameters that can differentiate these two diseases. For example, retinal A $\beta$ 
deposits appear in both $\mathrm{AMD}$ and $\mathrm{AD}$. In patients with $\mathrm{AD}, \mathrm{A} \beta$ deposition is observed in many retinal layers such as the GCL, RNFL, OPL, ONL, INL, and IPL. In contrast, in AMD, $\mathrm{A} \beta$ deposits are associated with drusen, which are formed by various sediments and exist in the retinal pigment epithelium and Bruch's membrane $[150,151]$. In addition, retinal degeneration in AMD occurs mainly in the macular, RPE, and photoreceptor layers [144], whereas retinal degeneration in AD predominantly occurs in the RNFL and GCL [152]. Moreover, the vascular changes in AMD, which feature choroidal neovascularization (detected by fluorescein angiography), are not reported in AD [153,154]. Furthermore, the $A p o E$ gene is associated with both AMD and AD $[155,156]$. There are three known isoforms of ApoE: ApoE2, ApoE3, and ApoE4 [155]. Interestingly, the ApoE4 isoform is a genetic risk factor for $\mathrm{AD}$ and might be associated with cognitive function; conversely, $A p o E 2$ serves as a protective element against AD $[157,158]$. However, ApoE2 is considered a risk gene that promotes AMD progression, whereas ApoE4 does the opposite [156]. These different features could be used to develop new strategies to distinguish AD and AMD and develop disease-specific biomarkers.

\subsection{Retinal Dysfunction in Glaucoma}

Glaucoma is another ophthalmological disorder that features RGC degeneration and optic nerve damage [159]. Glaucoma is reported to significantly increase the risk of $\mathrm{AD}[146,160]$, and the occurrence of glaucoma is significantly elevated among patients with $\mathrm{AD}$ [161]. Both of these diseases involve progressive degeneration and loss of RGCs [162]. Similar to the $A \beta$ and tau aggregation observed in the AD retina, $A \beta$ and hyperphosphorylated tau along with RGC degeneration are also reportedly involved in glaucoma pathology $[102,136,163]$. A $\beta$ was observed in the optic nerve and RGC layer in the glaucoma DBA/2J mouse model and might contribute to RGC loss [164]. Consistently, several studies indicate that RGC death is related to A $\beta$ toxicity in glaucoma $[136,165]$. In human glaucoma, abnormal tau (AT8) is localized in the INL [102], and in the rat glaucoma model, retinal tau (K9JA) accumulates dramatically in the IPL and is modestly increased in the GCL [166], while tau accumulates in the OPL, GCL, IPL, and RNFL of the retina in AD. $\mathrm{AD}$ and glaucoma share other similarities such as GCL thickness and blood-retinal barrier breakdown [163], making these retinal biomarkers nonspecific for the early identification of AD.

However, the vessel density of DVP was decreased in patients with AD, whereas the vessel density of the superficial vascular plexus and radial peripapillary capillary were reduced in patients with primary open-angle glaucoma [167]. Importantly, intraocular pressure (IOP) is considered a significant factor in the development of glaucoma [168], but the incidence of ocular hypertension was absent in patients with $\mathrm{AD} \mathrm{[161],} \mathrm{suggesting} \mathrm{that}$ IOP is not associated with AD pathology and may be a pivotal factor in differentiating $\mathrm{AD}$ and glaucoma.

\subsection{Strategies to Distinguish Alzheimer's Disease from Age-Related Macular Degeneration and Glaucoma}

Given that AD shares similarities with AMD and glaucoma (Table 2), a single retinal biomarker may be insufficient for detecting AD. Nevertheless, it is possible to distinguish $\mathrm{AD}$ from other ophthalmological diseases through combining multidimensional biomarkers or examining other retinal changes to exclude AMD and glaucoma. For example, multimodal imaging - including color photography, spectral-domain OCT, and fluorescein angiography - is used to detect specific symptoms of AMD such as drusen, pigment abnormalities, geographic atrophy, and neovascularization [144]. In contrast, these symptoms do not appear in $\mathrm{AD}$. In addition, the differences in the optic nerve head between $\mathrm{AD}$ and glaucoma measured by confocal scanning laser tomography can successfully differentiate glaucoma from AD [169]. Meanwhile, as high IOP is an important factor in glaucoma progression, IOP examination may be used to differentiate AD and glaucoma. A recent study shows that combining quantitative assessment of inner retinal layer and outer retinal layer thickness with DVP density may be a helpful approach for differentiating AD and primary 
open-angle glaucoma [167]. Furthermore, combining other AD-associated biomarkers, including CSF $A \beta$, tau, and amyloid PET, with structural MRI may be an alternative way to distinguish $\mathrm{AD}$ from other disorders, including ophthalmological diseases [170].

Table 2. Comparison of retinal changes in Alzheimer's disease, age-related macular degeneration, and glaucoma.

\begin{tabular}{|c|c|c|c|}
\hline Symptom & AD & AMD & Glaucoma \\
\hline Retinal thickness & $\begin{array}{l}\text { Thinning in the RNFL, } \\
\text { GC-IPL, and GCC of the } \\
\text { retina }[29,31,171,172]\end{array}$ & $\begin{array}{l}\text { Thinning in the macular } \\
\text { region and photoreceptor } \\
\text { layers [173] }\end{array}$ & $\begin{array}{l}\text { Thinning in the GCL and } \\
\text { RNFL of the retina [163] }\end{array}$ \\
\hline Electrophysiology & $\begin{array}{l}\text { PERG and PVEP } \\
\text { changes }[17,18]\end{array}$ & $\begin{array}{l}\text { Full-field ERG and multifocal } \\
\text { ERG changes [174] }\end{array}$ & $\begin{array}{l}\text { PERG and PVEP } \\
\text { changes [175] }\end{array}$ \\
\hline $\mathrm{A} \beta$ deposition & In the inner retina $[64,65,143]$ & Along with drusen $[150,151]$ & $\begin{array}{l}\text { In the optic nerve and RGC } \\
\text { layer of the retina [164] }\end{array}$ \\
\hline Tau accumulation & $\begin{array}{l}\text { In the OPL, IPL, GCL, and } \\
\text { RNFL of the retina }[3,83]\end{array}$ & $\mathrm{N}$ & $\begin{array}{l}\text { In the INL, IPL, and GCL of } \\
\text { the retina }[102,166]\end{array}$ \\
\hline Apoptosis & RGC apoptosis [176] & $\begin{array}{c}\text { Apoptosis of the RPE, } \\
\text { photoreceptors, and INL } \\
\text { cells [177] }\end{array}$ & RGC apoptosis [178] \\
\hline Ocular hypertension & $\begin{array}{l}\text { Ocular hypertension was } \\
\text { absent in patients with } \\
\text { AD [161] }\end{array}$ & $\mathrm{N}$ & $\begin{array}{c}\text { Elevated IOP in high-tension } \\
\text { glaucoma and normal IOP in } \\
\text { normal-tension } \\
\text { glaucoma }[168,179]\end{array}$ \\
\hline
\end{tabular}

\begin{tabular}{lccl}
\hline Hyperpigmentation & $\mathrm{N}$ & $\begin{array}{c}\text { Hyperpigmentation is present } \\
\text { in AMD patients [180] }\end{array}$ & $\mathrm{N}$ \\
\hline Geographic atrophy & $\mathrm{N}$ & $\begin{array}{c}\text { Geographic atrophy surround } \\
\text { and spare the central } \\
\text { macula [144] }\end{array}$ & $\mathrm{N}$ \\
\hline Choroidal neovascularization & $\mathrm{N}$ & $\begin{array}{c}\text { Choroidal neovascularization } \\
\text { is present in neovascular } \\
\text { AMD [181] }\end{array}$ & $\mathrm{N}$ \\
\hline
\end{tabular}

A $\beta$, amyloid-beta; AD, Alzheimer's disease; AMD, age-related macular degeneration; ERG, electroretinogram; GCC, ganglion cell complex; GC-IPL, ganglion cell-inner plexiform layer; GCL, ganglion cell layer; INL, inner nuclear layer; IOP, intraocular pressure; IPL, inner plexiform layer; MCI, mild cognitive impairment; N, Not found; OPL, outer plexiform layer; PERG, pattern electroretinogram; PVEP, pattern visual evoked potential; RGC, retinal ganglion cell; RNFL, retinal nerve fiber layer; RPE, retinal pigment epithelium.

\section{Future Directions and Challenges}

Given that the retina is a "window" into the brain and a good means of further investigating $\mathrm{AD}$ pathophysiology, examining retinal changes could be important for detecting early-stage AD. In this review, we highlighted several retinal abnormalities in $\mathrm{AD}$ - such as structural changes, alteration of electrophysiological properties, vascular variations, and $A \beta$ and tau accumulation - that ultimately lead to neuronal loss (Figure 1). Thus, using potential retinal biomarkers to detect early $\mathrm{AD}$ might be beneficial for patients with $\mathrm{AD}$ by enabling early intervention and consequently retarding disease progression (Tables 3 and 4). Although some studies propose monitoring retinal changes as a promising option for large-scale screening of the AD patient population, establishing specific and accurate retinal biomarkers for detecting early-stage $\mathrm{AD}$ is challenging. Some retinal biomarkers may be inadequate and nonspecific for detecting $\mathrm{AD}$, for example, because of overlapping changes between AD and other diseases such as AMD, glaucoma, vascular dementia, and Parkinson's disease. Meanwhile, other factors influence retinal alterations, such as genetics, age, and other comorbidities. Variation of the pathological features across patients with $\mathrm{AD}$ also increases the challenge of differentiating early-stage $\mathrm{AD}$ individuals from healthy individuals (Table 5). 


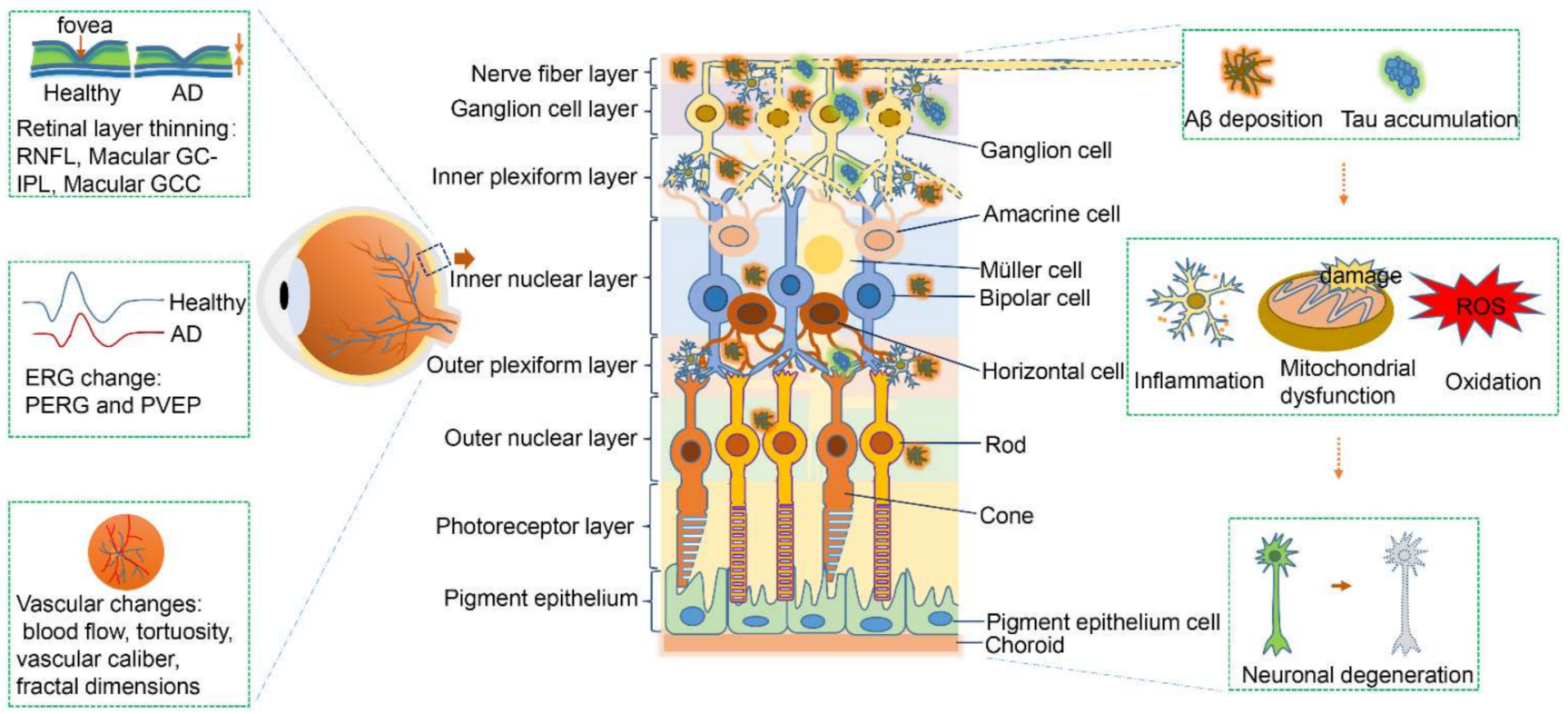

Figure 1. Schematic summary of retinal abnormalities in Alzheimer's disease. In Alzheimer's disease (AD) pathogenesis, amyloid-beta $(\mathrm{A} \beta)$ deposition and tau aggregation induce pathological cascades including neuronal inflammation as well as mitochondrial dysfunction and oxidation, which ultimately result in neuronal loss and degeneration. Meanwhile, in AD, the retina manifests electroretinographic changes, retinal thinning, and vascular changes. ERG, electroretinogram; GCC, ganglion cell complex; GC-IPL, ganglion cell-inner plexiform layer; PERG, pattern electroretinogram; PVEP, pattern visual evoked potential; RNFL, retinal nerve fiber layer; ROS, reactive oxygen species.

Table 3. Description of potential techniques for monitoring Alzheimer's disease.

\begin{tabular}{|c|c|c|}
\hline Techniques & Description & Main Findings \\
\hline $\begin{array}{l}\text { Spectral-domain optical } \\
\text { coherence tomography }\end{array}$ & $\begin{array}{l}\text { A noninvasive method that provides } \\
\text { high-resolution images of retinal } \\
\text { morphological structures and volumetric } \\
\text { parameters [130] }\end{array}$ & $\begin{array}{l}\text { Reduction in RNFL thickness }[29,31,171,172] \\
\text { Decrease in macular thickness and volume }[31] \\
\text { Reduction in macular GC-IPL thickness }[29,31] \\
\text { Reduction in macular GCC thickness }[31,32]\end{array}$ \\
\hline $\begin{array}{l}\text { Optical coherence } \\
\text { tomography-angiography }\end{array}$ & $\begin{array}{l}\text { A noninvasive method that can accurately } \\
\text { visualize the vascular system of different } \\
\text { retinal layers at a 3-dimensional level [110] }\end{array}$ & $\begin{array}{l}\text { Decrease in the microvascular density of deep retinal capillary } \\
\text { plexuses [110] }\end{array}$ \\
\hline $\begin{array}{l}\text { Doppler optical coherence } \\
\text { tomography and laser } \\
\text { Doppler blood flowmeter }\end{array}$ & $\begin{array}{l}\text { Noninvasive methods that can visualize and } \\
\text { quantify blood flow [133] }\end{array}$ & $\begin{array}{c}\text { Reduction in venous blood flow [134] } \\
\text { Decrease in retinal arterial blood flow [135] }\end{array}$ \\
\hline $\begin{array}{l}\text { Retinal photography } \\
\text { (ocular fundus) }\end{array}$ & $\begin{array}{l}\text { A noninvasive method that provides retinal } \\
\text { images and vascular signs [130] }\end{array}$ & $\begin{array}{c}\text { Narrowing of venular calibers [107] } \\
\text { Reduction in arteriolar and venular fractal dimensions [107,109] } \\
\text { Increase in tortuosity of arterioles and venules [107] } \\
\text { Detection of retinal A } \beta \text { plaques after curcumin } \\
\text { administration }[60]\end{array}$ \\
\hline $\begin{array}{l}\text { Pattern electroretinogram and } \\
\text { pattern visual evoked } \\
\text { potential }\end{array}$ & $\begin{array}{l}\text { Noninvasive methods that reflect the } \\
\text { bioelectrical functions of the retina and optic } \\
\text { nerve related to visual pathway } \\
\text { transmission [17] }\end{array}$ & $\begin{array}{c}\text { Increase in implicit time of P50 [17,18] } \\
\text { Amplitude reduction in both P50 and N95 [17,18] } \\
\text { Increase in P100-wave latency }[17,18] \\
\text { Increase in retinocortical time [17] }\end{array}$ \\
\hline Hyperspectral imaging & $\begin{array}{c}\text { A noninvasive method that detects retinal } \mathrm{A} \beta \\
\text { without extrinsic fluorescence labeling by } \\
\text { scanning within a specific wavelength } \\
\text { range [88] }\end{array}$ & Detection of retinal $\mathrm{A} \beta$ signature $[84,90]$ \\
\hline $\begin{array}{l}\text { Detection of apoptosing } \\
\text { retinal cells }\end{array}$ & $\begin{array}{l}\text { A method that allows real-time observation of } \\
\text { retinal apoptotic cells in vivo [139] }\end{array}$ & RGC apoptosis in $3 \times$ Tg-AD mice (a mouse model of AD) [176] \\
\hline
\end{tabular}

$\mathrm{A} \beta$, amyloid-beta; $\mathrm{AD}$, Alzheimer's disease; GCC, ganglion cell complex; GC-IPL, ganglion cell-inner plexiform layer; RGC, retinal ganglion cell; RNFL, retinal nerve fiber layer. 
Table 4. Potential retinal biomarkers for Alzheimer's disease.

\begin{tabular}{|c|c|c|}
\hline Pathology & Detection Methods & Expected Outcomes \\
\hline \multicolumn{3}{|l|}{ AD pathology } \\
\hline Amyloid deposition & $\begin{array}{l}\text { Retinal imaging } \\
\text { Hyperspectral imaging }\end{array}$ & $\begin{array}{l}\text { Detects retinal } A \beta \text { plaques after curcumin } \\
\text { administration }[60] \\
\text { Detects retinal } A \beta \text { signature }[84,90]\end{array}$ \\
\hline BACE1 expression & Currently unavailable in patients with AD & No information \\
\hline Tau aggregation & Currently unavailable in patients with AD & No information \\
\hline \multicolumn{3}{|l|}{ Non-AD pathology } \\
\hline \multicolumn{3}{|l|}{ Structural changes } \\
\hline RNFL thickness & \multirow{3}{*}{ Optical coherence tomography } & Decrease in RNFL thickness $[29,31,171,172]$ \\
\hline GC-IPL thickness & & Decrease in macular GC-IPL thickness $[29,31]$ \\
\hline Macular GCC thickness & & Decrease in macular GCC thickness $[31,32]$ \\
\hline \multicolumn{3}{|c|}{ Electrophysiological changes } \\
\hline PERG parameters & PERG examination & $\begin{array}{l}\text { Increase in implicit time of P50 }[17,18] \\
\text { Amplitude reduction in both P50 and } \\
\text { N95 }[17,18]\end{array}$ \\
\hline PVEP parameters & PVEP examination & Increase in P100-wave latency $[17,18]$ \\
\hline \multicolumn{3}{|l|}{ Vascular changes } \\
\hline RVPs & $\begin{array}{l}\text { Retinal photography } \\
\text { Doppler optical coherence tomography and laser } \\
\text { Doppler blood flowmeter }\end{array}$ & $\begin{array}{l}\text { Narrowing of venular calibers [107] } \\
\text { Reduction in arteriolar and venular fractal } \\
\text { dimensions [107,109] } \\
\text { Increase in tortuosity of arterioles and } \\
\text { venules [107] }\end{array}$ \\
\hline Apoptosis & $\begin{array}{l}\text { Detection of apoptosing retinal cells in vivo } \\
\text { Currently unavailable in patients with AD }\end{array}$ & $\begin{array}{l}\text { Detected RGC apoptosis in } 3 \times \mathrm{Tg} \text {-AD mice } \\
\text { (a mouse model of AD) [176] }\end{array}$ \\
\hline
\end{tabular}

$\mathrm{A} \beta$, amyloid-beta; AD, Alzheimer's disease; BACE1, $\beta$-site APP-cleaving enzyme 1; GCC, ganglion cell complex; GC-IPL, ganglion cell-inner plexiform layer; PERG, pattern electroretinogram; PVEP, pattern visual evoked potential; RGC, retinal ganglion cell; RNFL, retinal nerve fiber layer; RVPs, retinal vascular parameters.

Table 5. Comparison of different studies on the retinal changes in Alzheimer's disease.

\begin{tabular}{|c|c|c|}
\hline Retinal Indicators & Results & Contradictory Findings \\
\hline Retinal thickness & $\begin{array}{l}\text { Reduction in RNFL, GC-IPL, and macular GCC } \\
\text { thickness }[29,31,171,172]\end{array}$ & $\begin{array}{l}\text { No differences in macular retinal layer } \\
\text { thickness and pRNFL thickness }[33,34]\end{array}$ \\
\hline$A \beta$ plaques & Retinal $\mathrm{A} \beta$ plaques in patients with $\mathrm{AD}[64,65,143]$ & $\begin{array}{c}\text { No A } \beta \text { plaques in the retina in patients with } \\
\text { AD [20,81-83], or APP/PS1 or Tg2576 } \\
\text { mice [81] }\end{array}$ \\
\hline BACE1 expression & Detected in the retina of APP/PS1 mice [59] & $\mathrm{N}$ \\
\hline Tau aggregation & $\begin{array}{l}\text { Hyperphosphorylated tau and total tau found in the retina in patients } \\
\text { with } \operatorname{AD}[3,83]\end{array}$ & $\begin{array}{l}\text { No fibrillary tau, paired helical filaments, or } \\
\text { neurofibrillary tangles in } \mathrm{AD}[81,83]\end{array}$ \\
\hline PERG and PVEP & Changes in PERG and PVEP parameters $[17,18]$ & $\begin{array}{l}\text { No changes in PERG and PVEP } \\
\text { parameters [182] }\end{array}$ \\
\hline $\begin{array}{l}\text { Retinal vasculature } \\
\text { changes }\end{array}$ & $\begin{array}{l}\text { Decrease in the retinal microvascular density of the DRCPs [110] } \\
\text { Narrowing of venular calibers [107] } \\
\text { Reduction in arteriolar and venular fractal dimensions [107,109] } \\
\text { Increase in tortuosity of arterioles and venules [107] } \\
\text { Decrease in venous blood flow and retinal arterial blood flow [134] }\end{array}$ & $\begin{array}{c}\text { Decrease in arteriolar tortuosity [109] } \\
\text { No significant change in the density of } \\
\text { DVP }[124,125]\end{array}$ \\
\hline RGC apoptosis & RGC apoptosis in $3 \times$ Tg-AD mice (a mouse model of AD) [176] & $\mathrm{N}$ \\
\hline
\end{tabular}

$\mathrm{A} \beta$, amyloid-beta; $\mathrm{AD}$, Alzheimer's disease; BACE1, beta-site amyloid precursor protein cleaving enzyme 1; DRCPs, deep retinal capillary plexuses; GCC, ganglion cell complex; GC-IPL, ganglion cell-inner plexiform layer; N, Not found; PERG, pattern electroretinogram; pRNFL, peripapillary RNFL; PVEP, pattern visual evoked potential; RGC, retinal ganglion cell; RNFL, retinal nerve fiber layer; DVP, deep vascular plexus. 
Future studies using standardized protocols across different cohorts, in combination with patient stratification by precision medicine approaches, will help solve these discrepancies. To discover the specific retinal changes in AD pathology, future research can be directed to analyzing the retinal abnormalities in a larger population of patients through standardized classification-adjusting for age, race, genetics, and excluding other neurological or ophthalmological diseases-and then use of standard methodologies for further analysis. Moreover, although $\mathrm{A} \beta$ and tau are reportedly present in some layers of the retina, whether they are specifically localized in different cell types remains unclear. Hence, further studies are required to clarify the molecular mechanisms underlying retinal changes in AD as well as to improve the accuracy and universality of retinal biomarkers for AD.

Funding: This study was supported in part by the National Key R\&D Program of China (2018YFE0203600), the Guangdong Provincial Fund for Basic and Applied Basic Research (2019B1515130004), the NSFC-RGC Joint Research Scheme (32061160472), the Guangdong Provincial Key S\&T Program (2018B030336001), the Research Grants Council of Hong Kong (Theme-Based Research Scheme [T13607/12R]), the Areas of Excellence Scheme of the University Grants Committee (AoE/M-604/16), the Innovation and Technology Commission (ITCPD/17-9 and INNOHK18SC01), the Shenzhen Knowledge Innovation Program (JCYJ20170413165053031), and the Guangdong-Hong Kong-Macao Greater Bay Area Center for Brain Science and Brain-Inspired Intelligence Fund (2019001).

Acknowledgments: We apologize to the many authors whose excellent studies were not cited in this review because of space limitations. We thank the members of the Ip Laboratory for their helpful discussions and insights.

Conflicts of Interest: The authors declare no conflict of interest.

\section{References}

1. Goedert, M.; Spillantini, M.G. A Century of Alzheimer's Disease. Science 2006, 314, 777-781. [CrossRef] [PubMed]

2. Jack, C.R., Jr.; Albert, M.S.; Knopman, D.S.; McKhann, G.M.; Sperling, R.A.; Carrillo, M.C.; Thies, B.; Phelps, C.H. Introduction to the recommendations from the National Institute on Aging-Alzheimer's Association workgroups on diagnostic guidelines for Alzheimer's disease. Alzheimer's Dement. 2011, 7, 257-262. [CrossRef]

3. Gupta, V.B.; Chitranshi, N.; den Haan, J.; Mirzaei, M.; You, Y.; Lim, J.K.; Basavarajappa, D.; Godinez, A.; Di Angelantonio, S.; Sachdev, P.; et al. Retinal changes in Alzheimer's disease- integrated prospects of imaging, functional and molecular advances. Prog. Retin. Eye Res. 2020, 82, 100899. [CrossRef] [PubMed]

4. Molinuevo, J.L.; Ayton, S.; Batrla, R.; Bednar, M.M.; Bittner, T.; Cummings, J.; Fagan, A.M.; Hampel, H.; Mielke, M.; Mikulskis, A.; et al. Current state of Alzheimer's fluid biomarkers. Acta Neuropathol. 2018, 136, 821-853. [CrossRef]

5. Bacioglu, M.; Maia, L.F.; Preische, O.; Schelle, J.; Apel, A.; Kaeser, S.A.; Schweighauser, M.; Eninger, T.; Lambert, M.; Pilotto, A.; et al. Neurofilament Light Chain in Blood and CSF as Marker of Disease Progression in Mouse Models and in Neurodegenerative Diseases. Neuron 2016, 91, 56-66. [CrossRef]

6. Mattsson, N.; Schöll, M.; Strandberg, O.; Smith, R.; Palmqvist, S.; Insel, P.S.; Hägerström, D.; Ohlsson, T.; Zetterberg, H.; Jögi, J.; et al. 18 F-AV-1451 and CSF T-tau and P-tau as biomarkers in Alzheimer's disease. EMBO Mol. Med. 2017, 9, $1212-1223$. [CrossRef]

7. Janelidze, S.; Mattsson, N.; Palmqvist, S.; Smith, R.; Beach, T.G.; Serrano, G.E.; Chai, X.; Proctor, N.K.; Eichenlaub, U.; Zetterberg, H.; et al. Plasma P-tau181 in Alzheimer's disease: Relationship to other biomarkers, differential diagnosis, neuropathology and longitudinal progression to Alzheimer's dementia. Nat. Med. 2020, 26, 379-386. [CrossRef]

8. Jindal, V. Interconnection Between Brain and Retinal Neurodegenerations. Mol. Neurobiol. 2014, 51, 885-892. [CrossRef]

9. Barnstable, C.J. A molecular view of vertebrate retinal development. Mol. Neurobiol. 1987, 1, 9-46. [CrossRef]

10. Vecino, E.; Rodriguez, F.D.; Ruzafa, N.; Pereiro, X.; Sharma, S.C. Glia-neuron interactions in the mammalian retina. Prog. Retin. Eye Res. 2016, 51, 1-40. [CrossRef]

11. Kolb, H. How the retina works-Much of the construction of an image takes place in the retina itself through the use of specialized neural circuits. Am. Sci. 2003, 91, 28-35. [CrossRef]

12. London, A.; Benhar, I.; Schwartz, M. The retina as a window to the brain-from eye research to CNS disorders. Nat. Rev. Neurol. 2012, 9, 44-53. [CrossRef]

13. Alber, J.; Goldfarb, D.; Thompson, L.I.; Arthur, E.; Hernandez, K.; Cheng, D.; DeBuc, D.C.; Cordeiro, F.; Provetti-Cunha, L.; Haan, J.D.; et al. Developing retinal biomarkers for the earliest stages of Alzheimer's disease: What we know, what we don't, and how to move forward. Alzheimer's Dement. 2020, 16, 229-243. [CrossRef]

14. Snyder, P.J.; Johnson, L.N.; Lim, Y.Y.; Santos, C.Y.; Alber, J.; Maruff, P.; Fernández, B. Nonvascular retinal imaging markers of preclinical Alzheimer's disease. Alzheimer's Dement. 2016, 4, 169-178. [CrossRef] [PubMed] 
15. Czakó, C.; Kovács, T.; Ungvari, Z.; Csiszar, A.; Yabluchanskiy, A.; Conley, S.; Csipo, T.; Lipecz, A.; Horváth, H.; Sándor, G.L.; et al. Retinal biomarkers for Alzheimer's disease and vascular cognitive impairment and dementia (VCID): Implication for early diagnosis and prognosis. GeroScience 2020, 42, 1499-1525. [CrossRef]

16. Townes-Anderson, E.; Vogt, B.A. Distribution of muscarinic acetylcholine receptors on processes of isolated retinal cells. J. Comp. Neurol. 1989, 290, 369-383. [CrossRef]

17. Krasodomska, K.; Lubiński, W.; Potemkowski, A.; Honczarenko, K. Pattern electroretinogram (PERG) and pattern visual evoked potential (PVEP) in the early stages of Alzheimer's disease. Doc. Ophthalmol. 2010, 121, 111-121. [CrossRef]

18. Ngoo, Q.Z.; Hitam, W.H.W.; Ab Razak, A. Evaluation of Retinal Nerve Fiber Layer Thickness, Electroretinogram and Visual Evoked Potential in Patients with Alzheimer's Disease. J. Ophthalmol. 2019, 2019, 16248185. [CrossRef] [PubMed]

19. Hinton, D.R.; Sadun, A.A.; Blanks, J.C.; Miller, C.A. Optic-Nerve Degeneration in Alzheimer's Disease. N. Engl. J. Med. 1986, 315, 485-487. [CrossRef]

20. Blanks, J.C.; Hinton, D.R.; Sadun, A.A.; Miller, C.A. Retinal ganglion cell degeneration in Alzheimer's disease. Brain Res. 1989, 501, 364-372. [CrossRef]

21. Coppola, G.; di Renzo, A.; Ziccardi, L.; Martelli, F.; Fadda, A.; Manni, G.; Barboni, P.; Pierelli, F.; Sadun, A.A.; Parisi, V. Optical Coherence Tomography in Alzheimer's Disease: A Meta-Analysis. PLoS ONE 2015, 10, e0134750. [CrossRef]

22. Danesh-Meyer, H.V.; Birch, H.; Ku, J.Y.-F.; Carroll, S.; Gamble, G. Reduction of optic nerve fibers in patients with Alzheimer disease identified by laser imaging. Neurology 2006, 67, 1852-1854. [CrossRef]

23. Berisha, F.; Feke, G.T.; Trempe, C.L.; McMeel, J.W.; Schepens, C.L. Retinal Abnormalities in Early Alzheimer's Disease. Investig. Opthalmol. Vis. Sci. 2007, 48, 2285-2289. [CrossRef]

24. Gao, L.; Liu, Y.; Li, X.; Bai, Q.; Liu, P. Abnormal retinal nerve fiber layer thickness and macula lutea in patients with mild cognitive impairment and Alzheimer's disease. Arch. Gerontol. Geriatr. 2015, 60, 162-167. [CrossRef]

25. Paquet, C.; Boissonnot, M.; Roger, F.; Dighiero, P.; Gil, R.; Hugon, J. Abnormal retinal thickness in patients with mild cognitive impairment and Alzheimer's disease. Neurosci. Lett. 2007, 420, 97-99. [CrossRef]

26. Kesler, A.; Vakhapova, V.; Korczyn, A.D.; Naftaliev, E.; Neudorfer, M. Retinal thickness in patients with mild cognitive impairment and Alzheimer's disease. Clin. Neurol. Neurosurg. 2011, 113, 523-526. [CrossRef]

27. Blanks, J.C.; Torigoe, Y.; Hinton, D.R.; Blanks, R.H. Retinal pathology in Alzheimer's disease. I. Ganglion cell loss in foveal/parafoveal retina. Neurobiol. Aging 1996, 17, 377-384. [CrossRef]

28. Blanks, J.C.; Schmidt, S.Y.; Torigoe, Y.; Porrello, K.V.; Hinton, D.R.; Blanks, R.H. Retinal pathology in Alzheimer's disease. II. Regional neuron loss and glial changes in GCL. Neurobiol. Aging 1996, 17, 385-395. [CrossRef]

29. Cheung, C.Y.-L.; Ong, Y.T.; Hilal, S.; Ikram, M.K.; Low, S.; Venketasubramanian, N.; Yap, P.; Seow, D.; Chen, C.L.H.; Wong, T.Y. Retinal Ganglion Cell Analysis Using High-Definition Optical Coherence Tomography in Patients with Mild Cognitive Impairment and Alzheimer's Disease. J. Alzheimer's Dis. 2015, 45, 45-56. [CrossRef]

30. López-De-Eguileta, A.; Lage, C.; López-García, S.; Pozueta, A.; García-Martínez, M.; Kazimierczak, M.; Bravo, M.; De ArcochaTorres, M.; Banzo, I.; Jimenez-Bonilla, J.; et al. Ganglion cell layer thinning in prodromal Alzheimer's disease defined by amyloid PET. Alzheimer's Dement. 2019, 5, 570-578. [CrossRef]

31. Chan, V.T.; Sun, Z.; Tang, S.; Chen, L.J.; Wong, A.; Tham, C.Y.C.; Wong, T.Y.; Chen, C.; Ikram, M.K.; Whitson, H.E.; et al. Spectral-Domain OCT Measurements in Alzheimer's Disease. Ophthalmology 2018, 126, 497-510. [CrossRef]

32. Bayhan, H.A.; Bayhan, S.A.; Celikbilek, A.; Tanık, N.; Gürdal, C. Evaluation of the chorioretinal thickness changes in Alzheimer's disease using spectral-domain optical coherence tomography. Clin. Exp. Ophthalmol. 2014, 43, 145-151. [CrossRef]

33. Van De Kreeke, J.A.; Nguyen, H.; Haan, J.D.; Konijnenberg, E.; Tomassen, J.; Braber, A.D.; Kate, M.T.; Collij, L.; Yaqub, M.; Van Berckel, B.; et al. Retinal layer thickness in preclinical Alzheimer's disease. Acta Ophthalmol. 2019, 97, 798-804. [CrossRef] [PubMed]

34. Pillai, J.A.; Bermel, R.; Bonner-Jackson, A.; Rae-Grant, A.; Fernandez, H.; Bena, J.; Jones, S.E.; Ehlers, J.P.; Leverenz, J.B. Retinal Nerve Fiber Layer Thinning in Alzheimer's Disease: A Case-Control Study in Comparison to Normal Aging, Parkinson's Disease, and Non-Alzheimer's Dementia. Am. J. Alzheimer's Dis. Other Dement. 2016, 31, 430-436. [CrossRef]

35. Strack, R. Improving optical coherence tomography. Nat. Methods 2019, 16, 957. [CrossRef]

36. Martínez-Lapiscina, E.H.; Arnow, S.; Wilson, J.A.; Saidha, S.; Preiningerova, J.L.; Oberwahrenbrock, T.; Brandt, A.U.; Pablo, L.E.; Guerrieri, S.; González-Suárez, I.; et al. Retinal thickness measured with optical coherence tomography and risk of disability worsening in multiple sclerosis: A cohort study. Lancet Neurol. 2016, 15, 574-584. [CrossRef]

37. Lamirel, C.; Newman, N.; Biousse, V. The use of optical coherence tomography in neurology. Rev. Neurol. Dis. 2009, 6, E105-E120. [PubMed]

38. Doustar, J.; Torbati, T.; Black, K.L.; Koronyo, Y.; Koronyo-Hamaoui, M. Optical Coherence Tomography in Alzheimer's Disease and Other Neurodegenerative Diseases. Front. Neurol. 2017, 8, 701. [CrossRef]

39. Garcia-Martin, E.S.; Rojas, B.; Ramírez, A.I.; De Hoz, R.; Salazar, J.J.; Yubero, R.; Gil, P.; Triviño, A.; Ramirez, J.M. Macular Thickness as a Potential Biomarker of Mild Alzheimer's Disease. Ophthalmology 2014, 121, 1149-1151.e3. [CrossRef]

40. Curcio, C.A.; Allen, K.A. Topography of ganglion cells in human retina. J. Comp. Neurol. 1990, 300, 5-25. [CrossRef]

41. Williams, P.A.; Thirgood, R.A.; Oliphant, H.; Frizzati, A.; Littlewood, E.; Votruba, M.; Good, M.A.; Williams, J.; Morgan, J.E. Retinal ganglion cell dendritic degeneration in a mouse model of Alzheimer's disease. Neurobiol. Aging 2013, 34, 1799-1806. [CrossRef] 
42. Sadun, A.A.; Borchert, M.; DeVita, E.; Hinton, D.R.; Bassi, C.J. Assessment of Visual Impairment in Patients With Alzheimer's Disease. Am. J. Ophthalmol. 1987, 104, 113-120. [CrossRef]

43. Kirby, E.; Bandelow, S.; Hogervorst, E. Visual Impairment in Alzheimer's Disease: A Critical Review. J. Alzheimer's Dis. 2010, 21, 15-34. [CrossRef]

44. Asanad, S.; Karanjia, R. Pattern Electroretinogram; StatPearls: Treasure Island, FL, USA, 2020.

45. Parisi, V.; Restuccia, R.; Fattapposta, F.; Mina, C.; Bucci, M.G.; Pierelli, F. Morphological and functional retinal impairment in Alzheimer's disease patients. Clin. Neurophysiol. 2001, 112, 1860-1867. [CrossRef]

46. Fiorentini, A.; Maffei, L.; Pirchio, M.; Spinelli, D.; Porciatti, V. The ERG in response to alternating gratings in patients with diseases of the peripheral visual pathway. Investig. Ophthalmol. Vis. Sci. 1981, 21, 490-493.

47. Parisi, V. Correlation between morphological and functional retinal impairment in patients affected by ocular hypertension, glaucoma, demyelinating optic neuritis and Alzheimer's disease. Semin. Ophthalmol. 2003, 18, 50-57. [CrossRef]

48. Celesia, G.G.; Kaufman, D.; Cone, S.B. Simultaneous recording of pattern electroretinography and visual evoked potentials in multiple sclerosis. A method to separate demyelination from axonal damage to the optic nerve. Arch. Neurol. 1986, 43, 1247-1252. [CrossRef]

49. You, Y.; Thie, J.; Klistorner, A.; Gupta, V.K.; Graham, S.L. Normalization of Visual Evoked Potentials Using Underlying Electroencephalogram Levels Improves Amplitude Reproducibility in Rats. Investig. Opthalmol. Vis. Sci. 2012, 53, 1473-1478. [CrossRef]

50. Rimmer, S.; Iragui, V.; Klauber, M.R.; Katz, B. Retinocortical time exhibits spatial selectivity. Investig. Ophthalmol. Vis. Sci. 1989, 30, 2045-2049. [CrossRef]

51. Odom, J.V.; Bach, M.; Barber, C.; Brigell, M.; Marmor, M.F.; Tormene, A.P.; Holder, G.E. Visual evoked potentials standard (2004). Doc. Ophthalmol. 2004, 108, 115-123. [CrossRef] [PubMed]

52. Celesia, G.G.; Kaufman, D. Pattern ERGs and visual evoked potentials in maculopathies and optic nerve diseases. Investig. Ophthalmol. Vis. Sci. 1985, 26, 726-735.

53. Katz, B.; Rimmer, S.; Iragui, V.; Katzman, R. Abnormal pattern electroretinogram in Alzheimer's disease: Evidence for retinal ganglion cell degeneration? Ann. Neurol. 1989, 26, 221-225. [CrossRef] [PubMed]

54. Partanen, J.; Hartikainen, P.; Könönen, M.; Jousmäki, V.; Soininen, H.; Riekkinen, P. Prolonged Latencies of Pattern Reversal Visual Evoked Early Potentials in Alzheimer Disease. Alzheimer Dis. Assoc. Disord. 1994, 8, 250-258. [CrossRef]

55. Lorenz, R.; Dodt, E.; Heider, W. Pattern electroretinogram peak times as a clinical means of discriminating retinal from optic nerve disease. Doc. Ophthalmol. 1989, 71, 307-320. [CrossRef] [PubMed]

56. Pollock, V.E.; Schneider, L.S.; Chui, H.C.; Henderson, V.; Zemansky, M.; Sloane, R.B. Visual evoked potentials in dementia: A meta-analysis and empirical study of Alzheimer's disease patients. Biol. Psychiatry 1989, 25, 1003-1013. [CrossRef]

57. Jack, C.R.; Bennett, D.A.; Blennow, K.; Carrillo, M.C.; Dunn, B.; Haeberlein, S.B.; Holtzman, D.M.; Jagust, W.; Jessen, F.; Karlawish, J.; et al. NIA-AA Research Framework: Toward a biological definition of Alzheimer's disease. Alzheimer's Dement. 2018, 14, 535-562. [CrossRef]

58. Zhang, Y.-W.; Thompson, R.; Zhang, H.; Xu, H. APP processing in Alzheimer's disease. Mol. Brain 2011, 4, 3. [CrossRef]

59. Wang, H.; Huang, J.-F.; Li, L.; Luo, J.; Chen, D.; Tong, J.-B.; Zeng, L.-P.; Cao, Y.-Q.; Xiang, J.; Luo, X.-G.; et al. BACE1 in the retina: A sensitive biomarker for monitoring early pathological changes in Alzheimer's disease. Neural Regen. Res. 2016, 11, 447-453. [CrossRef]

60. Koronyo-Hamaoui, M.; Koronyo, Y.; Ljubimov, A.V.; Miller, C.A.; Ko, M.K.; Black, K.L.; Schwartz, M.; Farkas, D.L. Identification of amyloid plaques in retinas from Alzheimer's patients and noninvasive in vivo optical imaging of retinal plaques in a mouse model. NeuroImage 2011, 54, S204-S217. [CrossRef]

61. Grimaldi, A.; Brighi, C.; Peruzzi, G.; Ragozzino, D.; Bonanni, V.; Limatola, C.; Ruocco, G.; Di Angelantonio, S. Inflammation, neurodegeneration and protein aggregation in the retina as ocular biomarkers for Alzheimer's disease in the 3xTg-AD mouse model. Cell Death Dis. 2018, 9, 685. [CrossRef]

62. Alexandrov, P.N.; Pogue, A.; Bhattacharjee, S.; Lukiw, W.J. Retinal amyloid peptides and complement factor H in transgenic models of Alzheimer's disease. NeuroReport 2011, 22, 623-627. [CrossRef] [PubMed]

63. Vandenabeele, M.; Veys, L.; Lemmens, S.; Hadoux, X.; Gelders, G.; Masin, L.; Serneels, L.; Theunis, J.; Saito, T.; Saido, T.C.; et al. The AppNL-G-F mouse retina is a site for preclinical Alzheimer's disease diagnosis and research. Acta Neuropathol. Commun. 2021, 9, 6. [CrossRef]

64. Hart, N.; Koronyo, Y.; Black, K.L.; Koronyo-Hamaoui, M. Ocular indicators of Alzheimer's: Exploring disease in the retina. Acta Neuropathol. 2016, 132, 767-787. [CrossRef]

65. Koronyo, Y.; Biggs, D.; Barron, E.; Boyer, D.S.; Pearlman, J.A.; Au, W.J.; Kile, S.J.; Blanco, A.; Fuchs, D.-T.; Ashfaq, A.; et al. Retinal amyloid pathology and proof-of-concept imaging trial in Alzheimer's disease. JCI Insight 2017, 2, e93621. [CrossRef]

66. Thal, D.R.; Rüb, U.; Orantes, M.; Braak, H. Phases of A $\beta$-deposition in the human brain and its relevance for the development of AD. Neurology 2002, 58, 1791-1800. [CrossRef]

67. Yang, L.-B.; Lindholm, K.; Yan, R.; Citron, M.; Xia, W.; Yang, X.-L.; Beach, T.; Sue, L.; Wong, P.; Price, D.; et al. Elevated $\beta$-secretase expression and enzymatic activity detected in sporadic Alzheimer disease. Nat. Med. 2003, 9, 3-4. [CrossRef] [PubMed] 
68. Li, R.; Lindholm, K.; Yang, L.-B.; Yue, X.; Citron, M.; Yan, R.; Beach, T.; Sue, L.; Sabbagh, M.; Cai, H.; et al. Amyloid peptide load is correlated with increased -secretase activity in sporadic Alzheimer's disease patients. Proc. Natl. Acad. Sci. USA 2004, 101, 3632-3637. [CrossRef] [PubMed]

69. Cheng, X.; He, P.; Lee, T.; Yao, H.; Li, R.; Shen, Y. High Activities of BACE1 in Brains with Mild Cognitive Impairment. Am. J. Pathol. 2014, 184, 141-147. [CrossRef]

70. Shankar, G.M.; Walsh, D.M. Alzheimer's disease: Synaptic dysfunction and A $\beta$. Mol. Neurodegener. 2009, 4, 48. [CrossRef] [PubMed]

71. Ferretti, M.T.; Bruno, M.A.; Ducatenzeiler, A.; Klein, W.L.; Cuello, C. Intracellular A $\beta$-oligomers and early inflammation in a model of Alzheimer's disease. Neurobiol. Aging 2012, 33, 1329-1342. [CrossRef] [PubMed]

72. Tönnies, E.; Trushina, E. Oxidative Stress, Synaptic Dysfunction, and Alzheimer's Disease. J. Alzheimer's Dis. 2017, 57, 1105-1121. [CrossRef]

73. Palop, J.J.; Mucke, L. Amyloid- $\beta$-induced neuronal dysfunction in Alzheimer's disease: From synapses toward neural networks. Nat. Neurosci. 2010, 13, 812-818. [CrossRef]

74. Mucke, L.; Selkoe, D.J. Neurotoxicity of Amyloid beta-Protein: Synaptic and Network Dysfunction. Cold Spring Harb. Perspect. Med. 2012, 2, a006338. [CrossRef] [PubMed]

75. Deng, L.; Pushpitha, K.; Joseph, C.; Gupta, V.; Rajput, R.; Chitranshi, N.; Dheer, Y.; Amirkhani, A.; Kamath, K.; Pascovici, D.; et al. Amyloid $\beta$ Induces Early Changes in the Ribosomal Machinery, Cytoskeletal Organization and Oxidative Phosphorylation in Retinal Photoreceptor Cells. Front. Mol. Neurosci. 2019, 12, 24. [CrossRef]

76. Ning, A.; Cui, J.; To, E.; Ashe, K.H.; Matsubara, J. Amyloid- $\beta$ Deposits Lead to Retinal Degeneration in a Mouse Model of Alzheimer Disease. Investig. Opthalmol. Vis. Sci. 2008, 49, 5136-5143. [CrossRef]

77. Liu, B.; Rasool, S.; Yang, Z.; Glabe, C.G.; Schreiber, S.S.; Ge, J.; Tan, Z. Amyloid-Peptide Vaccinations Reduce $\beta$-Amyloid Plaques but Exacerbate Vascular Deposition and Inflammation in the Retina of Alzheimer's Transgenic Mice. Am. J. Pathol. 2009, 175, 2099-2110. [CrossRef]

78. Perez, S.E.; Lumayag, S.; Kovacs, B.; Mufson, E.J.; Xu, S. $\beta$-Amyloid Deposition and Functional Impairment in the Retina of the APPswe/PS1 $\triangle$ E9 Transgenic Mouse Model of Alzheimer's Disease. Investig. Opthalmol. Vis. Sci. 2009, 50, 793-800. [CrossRef]

79. Mirzaei, M.; Pushpitha, K.; Deng, L.; Chitranshi, N.; Gupta, V.; Rajput, R.; Mangani, A.B.; Dheer, Y.; Godinez, A.; McKay, M.J.; et al. Upregulation of Proteolytic Pathways and Altered Protein Biosynthesis Underlie Retinal Pathology in a Mouse Model of Alzheimer's Disease. Mol. Neurobiol. 2019, 56, 6017-6034. [CrossRef]

80. Lim, J.; Li, Q.-X.; He, Z.; Vingrys, A.J.; Chinnery, H.R.; Mullen, J.; Bui, B.; Nguyen, C.T.O. Retinal Functional and Structural Changes in the 5xFAD Mouse Model of Alzheimer's Disease. Front. Neurosci. 2020, 14, 862. [CrossRef]

81. Schön, C.; Hoffmann, N.A.; Ochs, S.M.; Burgold, S.; Filser, S.; Steinbach, S.; Seeliger, W.M.; Arzberger, T.; Goedert, M.; Kretzschmar, H.A.; et al. Long-Term In Vivo Imaging of Fibrillar Tau in the Retina of P301S Transgenic Mice. PLoS ONE 2012, 7, e53547. [CrossRef]

82. Ho, C.-Y.; Troncoso, J.C.; Knox, D.; Stark, W.; Eberhart, C.G. Beta-Amyloid, Phospho-Tau and Alpha-Synuclein Deposits Similar to Those in the Brain Are Not Identified in the Eyes of Alzheimer's and Parkinson's Disease Patients. Brain Pathol. 2013, 24, 25-32. [CrossRef]

83. Haan, J.D.; Morrema, T.H.J.; Verbraak, F.D.; de Boer, J.; Scheltens, P.; Rozemuller, A.J.; Bergen, A.A.B.; Bouwman, F.H.; Hoozemans, J.J. Amyloid-beta and phosphorylated tau in post-mortem Alzheimer's disease retinas. Acta Neuropathol. Commun. 2018, 6, 147. [CrossRef]

84. Hadoux, X.; Hui, F.; Lim, J.K.H.; Masters, C.; Pébay, A.; Chevalier, S.; Ha, J.; Loi, S.; Fowler, C.J.; Rowe, C.; et al. Non-invasive in vivo hyperspectral imaging of the retina for potential biomarker use in Alzheimer's disease. Nat. Commun. 2019, $10,4227$. [CrossRef]

85. Yang, F.; Lim, G.P.; Begum, A.N.; Ubeda, O.J.; Simmons, M.R.; Ambegaokar, S.S.; Chen, P.P.; Kayed, R.; Glabe, C.G.; Frautschy, S.A.; et al. Curcumin Inhibits Formation of Amyloid $\beta$ Oligomers and Fibrils, Binds Plaques, and Reduces Amyloid in Vivo. J. Biol. Chem. 2005, 280, 5892-5901. [CrossRef]

86. Garcia-Alloza, M.; Borrelli, L.A.; Rozkalne, A.; Hyman, B.T.; Bacskai, B.J. Curcumin labels amyloid pathologyin vivo, disrupts existing plaques, and partially restores distorted neurites in an Alzheimer mouse model. J. Neurochem. 2007, 102, 1095-1104. [CrossRef]

87. Dhillon, N.; Aggarwal, B.B.; Newman, R.A.; Wolff, R.A.; Kunnumakkara, A.B.; Abbruzzese, J.L.; Ng, C.S.; Badmaev, V.; Kurzrock, R. Phase II Trial of Curcumin in Patients with Advanced Pancreatic Cancer. Clin. Cancer Res. 2008, 14, 4491-4499. [CrossRef]

88. More, S.S.; Vince, R. Hyperspectral Imaging Signatures Detect Amyloidopathy in Alzheimer's Mouse Retina Well before Onset of Cognitive Decline. ACS Chem. Neurosci. 2014, 6, 306-315. [CrossRef]

89. Lu, G.; Fei, B. Medical hyperspectral imaging: A review. J. Biomed. Opt. 2014, 19, 010901. [CrossRef] [PubMed]

90. More, S.S.; Beach, J.M.; McClelland, C.; Mokhtarzadeh, A.; Vince, R. In Vivo Assessment of Retinal Biomarkers by Hyperspectral Imaging: Early Detection of Alzheimer's Disease. ACS Chem. Neurosci. 2019, 10, 4492-4501. [CrossRef]

91. Gupta, V.B.; Anitha, S.; Hegde, M.; Zecca, L.; Garruto, R.M.; Ravid, R.; Shankar, S.K.; Stein, R.; Shanmugavelu, P.; Rao, K.S.J. Aluminium in Alzheimer?s disease: Are we still at a crossroad? Cell. Mol. Life Sci. 2005, 62, 143-158. [CrossRef]

92. Goedert, M.; Spillantini, M.G.; Jakes, R.; Rutherford, D.; Crowther, R.A. Multiple isoforms of human microtubule-associated protein tau: Sequences and localization in neurofibrillary tangles of Alzheimer's disease. Neuron 1989, 3, 519-526. [CrossRef] 
93. Buerger, K.; Ewers, M.; Pirttilä, T.; Zinkowski, R.; Alafuzoff, I.; Teipel, S.J.; Debernardis, J.; Kerkman, D.; McCulloch, C.; Soininen, H.; et al. CSF phosphorylated tau protein correlates with neocortical neurofibrillary pathology in Alzheimer's disease. Brain 2006, 129, 3035-3041. [CrossRef]

94. Bejanin, A.; Schonhaut, D.; La Joie, R.; Kramer, J.H.; Baker, S.L.; Sosa, N.; Ayakta, N.; Cantwell, A.; Janabi, M.; Lauriola, M.; et al. Tau pathology and neurodegeneration contribute to cognitive impairment in Alzheimer's disease. Brain 2017, 140, 3286-3300. [CrossRef]

95. Cowan, C.M.; Bossing, T.; Page, A.; Shepherd, D.; Mudher, A. Soluble hyper-phosphorylated tau causes microtubule breakdown and functionally compromises normal tau in vivo. Acta Neuropathol. 2010, 120, 593-604. [CrossRef]

96. Andreasen, N.; Minthon, L.; Davidsson, P.; Vanmechelen, E.; Vanderstichele, H.; Winblad, B.; Blennow, K. Evaluation of CSF-tau and CSF-A 342 as Diagnostic Markers for Alzheimer Disease in Clinical Practice. Arch. Neurol. 2001, 58, 373-379. [CrossRef] [PubMed]

97. Gasparini, L.; Crowther, R.A.; Martin, K.R.; Berg, N.; Coleman, M.; Goedert, M.; Spillantini, M.G. Tau inclusions in retinal ganglion cells of human P301S tau transgenic mice: Effects on axonal viability. Neurobiol. Aging 2011, 32, 419-433. [CrossRef]

98. Lim, J.; Li, Q.-X.; He, Z.; Vingrys, A.; Wong, V.H.Y.; Currier, N.; Mullen, J.; Bui, B.; Nguyen, C.T.O. The Eye As a Biomarker for Alzheimer's Disease. Front. Neurosci. 2016, 10, 536. [CrossRef]

99. Chiasseu, M.; Alarcon-Martinez, L.; Belforte, N.; Quintero, H.; Dotigny, F.; Destroismaisons, L.; Velde, C.V.; Panayi, F.; Louis, C.; Di Polo, A. Tau accumulation in the retina promotes early neuronal dysfunction and precedes brain pathology in a mouse model of Alzheimer's disease. Mol. Neurodegener. 2017, 12, 58. [CrossRef] [PubMed]

100. Zhao, H.; Chang, R.; Che, H.; Wang, J.; Yang, L.; Fang, W.; Xia, Y.; Li, N.; Ma, Q.; Wang, X. Hyperphosphorylation of tau protein by calpain regulation in retina of Alzheimer's disease transgenic mouse. Neurosci. Lett. 2013, 551, 12-16. [CrossRef]

101. Nilson, A.N.; English, K.C.; Gerson, J.E.; Whittle, T.B.; Crain, C.N.; Xue, J.; Sengupta, U.; Castillo-Carranza, D.L.; Zhang, W.; Gupta, P.; et al. Tau Oligomers Associate with Inflammation in the Brain and Retina of Tauopathy Mice and in Neurodegenerative Diseases. J. Alzheimer's Dis. 2016, 55, 1083-1099. [CrossRef] [PubMed]

102. Gupta, N.; Fong, J.; Ang, L.C.; Yücel, Y.H. Retinal tau pathology in human glaucomas. Can. J. Ophthalmol. 2008, 43, 53-60. [CrossRef] [PubMed]

103. Knopman, D.S. Dementia and Cerebrovascular Disease. Mayo Clin. Proc. 2006, 81, 223-230. [CrossRef]

104. Toledo, J.; Arnold, S.E.; Raible, K.; Brettschneider, J.; Xie, S.X.; Grossman, M.; Monsell, S.E.; Kukull, W.A.; Trojanowski, J.Q. Contribution of cerebrovascular disease in autopsy confirmed neurodegenerative disease cases in the National Alzheimer's Coordinating Centre. Brain 2013, 136, 2697-2706. [CrossRef] [PubMed]

105. Kalaria, R.N. Neuropathological diagnosis of vascular cognitive impairment and vascular dementia with implications for Alzheimer's disease. Acta Neuropathol. 2016, 131, 659-685. [CrossRef]

106. Gorelick, P.B.; Scuteri, A.; Black, S.; DeCarli, C.; Greenberg, S.M.; Iadecola, C.; Launer, L.J.; Laurent, S.; Lopez, O.L.; Nyenhuis, D.; et al. Vascular contributions to cognitive impairment and dementia: A statement for healthcare professionals from the american heart association/american stroke association. Stroke 2011, 42, 2672-2713. [CrossRef]

107. Cheung, C.Y.-L.; Ong, Y.T.; Ikram, M.K.; Ong, S.Y.; Li, X.; Hilal, S.; Catindig, J.-A.S.; Venketasubramanian, N.; Yap, P.; Seow, D.; et al. Microvascular network alterations in the retina of patients with Alzheimer's disease. Alzheimer's Dement. 2014, 10, 135-142. [CrossRef]

108. Patton, N.; Aslam, T.; MacGillivray, T.; Pattie, A.; Deary, I.J.; Dhillon, B. Retinal vascular image analysis as a potential screening tool for cerebrovascular disease: A rationale based on homology between cerebral and retinal microvasculatures. J. Anat. 2005, 206, 319-348. [CrossRef]

109. Williams, M.; McGowan, A.J.; Cardwell, C.; Cheung, C.; Craig, D.W.; Passmore, P.; Silvestri, G.; Maxwell, A.P.; McKay, G.J. Retinal microvascular network attenuation in Alzheimer's disease. Alzheimer's Dement. 2015, 1, 229-235. [CrossRef]

110. Wu, J.; Zhang, X.; Azhati, G.; Li, T.; Xu, G.; Liu, F. Retinal microvascular attenuation in mental cognitive impairment and Alzheimer's disease by optical coherence tomography angiography. Acta Ophthalmol. 2020, 98, e781-e787. [CrossRef] [PubMed]

111. Sharafi, S.M.; Sylvestre, J.P.; Chevrefils, C.; Soucy, J.P.; Beaulieu, S.; Pascoal, T.A.; Arbour, J.D.; Rhéaume, M.; Robillard, A.; Chayer, C.; et al. Vascular retinal biomarkers improves the detection of the likely cerebral amyloid status from hyperspectral retinal images. Alzheimer's Dement. 2019, 5, 610-617. [CrossRef]

112. Frost, S.; the AIBL Research Group; Kanagasingam, Y.; Sohrabi, H.R.; Vignarajan, J.; Bourgeat, P.; Salvado, O.; Villemagne, V.; Rowe, C.C.; Macaulay, S.L.; et al. Retinal vascular biomarkers for early detection and monitoring of Alzheimer's disease. Transl. Psychiatry 2013, 3, e233. [CrossRef]

113. Ellis, R.J.; Olichney, J.M.; Thal, L.J.; Mirra, S.S.; Morris, J.C.; Beekly, D.; Heyman, A. Cerebral amyloid angiopathy in the brains of patients with Alzheimer's disease: The CERAD experience, Part XV. Neurology 1996, 46, 1592-1596. [CrossRef]

114. Arvanitakis, Z.; Leurgans, S.E.; Wang, Z.; Wilson, R.S.; Bennett, D.A.; Schneider, J.A. Cerebral amyloid angiopathy pathology and cognitive domains in older persons. Ann. Neurol. 2010, 69, 320-327. [CrossRef] [PubMed]

115. Viswanathan, A.; Greenberg, S.M. Cerebral amyloid angiopathy in the elderly. Ann. Neurol. 2011, 70, 871-880. [CrossRef]

116. Greenberg, S.M.; Bacskai, B.J.; Hernandez-Guillamon, M.; Pruzin, J.; Sperling, R.; Van Veluw, S.J. Cerebral amyloid angiopathy and Alzheimer disease - one peptide, two pathways. Nat. Rev. Neurol. 2019, 16, 30-42. [CrossRef] [PubMed]

117. Sweeney, M.; Sagare, A.P.; Zlokovic, B.V. Blood-brain barrier breakdown in Alzheimer disease and other neurodegenerative disorders. Nat. Rev. Neurol. 2018, 14, 133-150. [CrossRef] [PubMed] 
118. Trost, A.; Lange, S.; Schroedl, F.; Bruckner, D.; Motloch, K.A.; Bogner, B.; Kaser-Eichberger, A.; Strohmaier, C.; Runge, C.; Aigner, L.; et al. Brain and Retinal Pericytes: Origin, Function and Role. Front. Cell. Neurosci. 2016, 10, 20. [CrossRef]

119. Shi, H.; Koronyo, Y.; Rentsendorj, A.; Regis, G.C.; Sheyn, J.; Fuchs, D.-T.; Kramerov, A.A.; Ljubimov, A.V.; Dumitrascu, O.M.; Rodriguez, A.R.; et al. Identification of early pericyte loss and vascular amyloidosis in Alzheimer's disease retina. Acta Neuropathol. 2020, 139, 813-836. [CrossRef]

120. Tisi, A.; Feligioni, M.; Passacantando, M.; Ciancaglini, M.; Maccarone, R. The Impact of Oxidative Stress on Blood-Retinal Barrier Physiology in Age-Related Macular Degeneration. Cells 2021, 10, 64. [CrossRef]

121. Klaassen, I.; Van Noorden, C.J.; Schlingemann, R.O. Molecular basis of the inner blood-retinal barrier and its breakdown in diabetic macular edema and other pathological conditions. Prog. Retin. Eye Res. 2013, 34, 19-48. [CrossRef] [PubMed]

122. Giebel, S.J.; Menicucci, G.; McGuire, P.G.; Das, A. Matrix metalloproteinases in early diabetic retinopathy and their role in alteration of the blood-retinal barrier. Lab. Investig. 2005, 85, 597-607. [CrossRef]

123. Xu, H.; Forrester, J.V.; Liversidge, J.; Crane, I.J. Leukocyte trafficking in experimental autoimmune uveitis: Breakdown of blood-retinal barrier and upregulation of cellular adhesion molecules. Investig. Opthalmol. Vis. Sci. 2003, 44, 226-234. [CrossRef] [PubMed]

124. Jiang, H.; Wang, J.; Levin, B.E.; Baumel, B.S.; Camargo, C.J.; Signorile, J.F.; Rundek, T. Retinal Microvascular Alterations as the Biomarkers for Alzheimer Disease: Are We There Yet? J. Neuro-Ophthalmol. 2020, 41, 251-260. [CrossRef]

125. Querques, G.; Borrelli, E.; Sacconi, R.; De Vitis, L.; Leocani, L.; Santangelo, R.; Magnani, G.; Comi, G.; Bandello, F. Functional and morphological changes of the retinal vessels in Alzheimer's disease and mild cognitive impairment. Sci. Rep. $2019,9,63$. [CrossRef]

126. Tian, J.; Smith, G.; Guo, H.; Liu, B.; Pan, Z.; Wang, Z.; Xiong, S.; Fang, R. Modular machine learning for Alzheimer's disease classification from retinal vasculature. Sci. Rep. 2021, 11, 238. [CrossRef] [PubMed]

127. Ong, Y.-T.; Hilal, S.; Cheung, C.; Xu, X.; Chen, C.; Venketasubramanian, N.; Wong, T.Y.; Ikram, M.K. Retinal Vascular Fractals and Cognitive Impairment. Dement. Geriatr. Cogn. Disord. Extra 2014, 4, 305-313. [CrossRef] [PubMed]

128. Lai, A.Y.; Dorr, A.; Thomason, L.A.M.; Koletar, M.M.; Sled, J.G.; Stefanovic, B.; McLaurin, J. Venular degeneration leads to vascular dysfunction in a transgenic model of Alzheimer's disease. Brain 2015, 138, 1046-1058. [CrossRef]

129. Cheung, C.; Ikram, M.K.; Chen, C.; Wong, T.Y. Imaging retina to study dementia and stroke. Prog. Retin. Eye Res. 2017, 57, 89-107. [CrossRef]

130. Liao, H.; Zhu, Z.; Peng, Y. Potential Utility of Retinal Imaging for Alzheimer's Disease: A Review. Front. Aging Neurosci. 2018, 10, 188. [CrossRef]

131. Ikram, M.K.; Cheung, C.; Wong, T.Y.; Chen, C.P.L.H. Retinal pathology as biomarker for cognitive impairment and Alzheimer's disease. J. Neurol. Neurosurg. Psychiatry 2012, 83, 917-922. [CrossRef]

132. Jiang, H.; Wei, Y.; Shi, Y.; Wright, C.B.; Sun, X.; Gregori, G.; Zheng, F.; Vanner, E.A.; Lam, B.L.; Rundek, T.; et al. Altered Macular Microvasculature in Mild Cognitive Impairment and Alzheimer Disease. J. Neuroophthalmol. 2018, 38, 292-298. [CrossRef]

133. Leitgeb, R.A.; Werkmeister, R.M.; Blatter, C.; Schmetterer, L. Doppler Optical Coherence Tomography. Prog. Retin. Eye Res. 2014, 41, 26-43. [CrossRef] [PubMed]

134. Feke, G.T.; Hyman, B.T.; Stern, R.A.; Pasquale, L.R. Retinal blood flow in mild cognitive impairment and Alzheimer's disease. Alzheimer's Dement. 2015, 1, 144-151. [CrossRef]

135. Szegedi, S.; Dal-Bianco, P.; Stögmann, E.; Traub-Weidinger, T.; Rainer, M.; Masching, A.; Schmidl, D.; Werkmeister, R.M.; Chua, J.; Schmetterer, L.; et al. Anatomical and functional changes in the retina in patients with Alzheimer's disease and mild cognitive impairment. Acta Ophthalmol. 2020, 98, e914-e921. [CrossRef] [PubMed]

136. Yin, H.; Chen, L.; Chen, X.; Liu, X. Soluble amyloid $\beta$ oligomers may contribute to apoptosis of retinal ganglion cells in glaucoma. Med. Hypotheses 2008, 71,77-80. [CrossRef] [PubMed]

137. Smale, G.; Nichols, N.R.; Brady, D.R.; Finch, C.E.; Horton, W.E. Evidence for Apoptotic Cell Death in Alzheimer's Disease. Exp. Neurol. 1995, 133, 225-230. [CrossRef] [PubMed]

138. Su, J.H.; Anderson, A.J.; Cummings, B.J.; Cotman, C.W. Immunohistochemical evidence for apoptosis in Alzheimer's disease. NeuroReport 1994, 5, 2529-2533. [CrossRef]

139. Cordeiro, M.F.; Normando, E.M.; Cardoso, M.J.; Miodragovic, S.; Jeylani, S.; Davis, B.M.; Guo, L.; Ourselin, S.; A’Hern, R.; Bloom, P.A. Real-time imaging of single neuronal cell apoptosis in patients with glaucoma. Brain 2017, 140, 1757-1767. [CrossRef]

140. Mazzoni, F.; Müller, C.; DeAssis, J.; Lew, D.; Leevy, W.M.; Finnemann, S.C. Non-invasive in vivo fluorescence imaging of apoptotic retinal photoreceptors. Sci. Rep. 2019, 9, 1590. [CrossRef] [PubMed]

141. Kwong, J.M.K.; Hoang, C.; Dukes, R.T.; Yee, R.W.; Gray, B.D.; Pak, K.Y.; Caprioli, J. Bis(Zinc-Dipicolylamine), Zn-DPA, a New Marker for Apoptosis. Investig. Opthalmol. Vis. Sci. 2014, 55, 4913-4921. [CrossRef]

142. Ashok, A.; Singh, N.; Chaudhary, S.; Bellamkonda, V.; Kritikos, A.E.; Wise, A.S.; Rana, N.; McDonald, D.; Ayyagari, R. Retinal Degeneration and Alzheimer's Disease: An Evolving Link. Int. J. Mol. Sci. 2020, 21, 7290. [CrossRef]

143. Wang, L.; Mao, X. Role of Retinal Amyloid- $\beta$ in Neurodegenerative Diseases: Overlapping Mechanisms and Emerging Clinical Applications. Int. J. Mol. Sci. 2021, 22, 2360. [CrossRef]

144. Mitchell, P.; Liew, G.; Gopinath, B.; Wong, T.Y. Age-related macular degeneration. Lancet 2018, 392, 1147-1159. [CrossRef]

145. Klaver, C.; Ott, A.; Hofman, A.; Assink, J.J.M.; Breteler, M.M.; De Jong, P.T.V.M. Is Age-related Maculopathy Associated with Alzheimer's Disease?: The Rotterdam Study. Am. J. Epidemiol. 1999, 150, 963-968. [CrossRef] [PubMed] 
146. Lee, C.S.; Larson, E.B.; Gibbons, L.E.; Lee, A.Y.; McCurry, S.M.; Bowen, J.D.; McCormick, W.C.; Crane, P.K. Associations between recent and established ophthalmic conditions and risk of Alzheimer's disease. Alzheimer's Dement. 2018, 15, 34-41. [CrossRef] [PubMed]

147. Wen, L.-Y.; Wan, L.; Lai, J.-N.; Chen, C.S.; Chen, J.J.-Y.; Wu, M.-Y.; Hu, K.-C.; Chiu, L.-T.; Tien, P.-T.; Lin, H.-J. Increased risk of Alzheimer's disease among patients with age-related macular degeneration: A nationwide population-based study. PLoS ONE 2021, 16, e0250440. [CrossRef] [PubMed]

148. Williams, M.A.; Silvestri, V.; Craig, D.; Passmore, A.P.; Silvestri, G. The Prevalence of Age-Related Macular Degeneration in Alzheimer's Disease. J. Alzheimer's Dis. 2014, 42, 909-914. [CrossRef]

149. Ohno-Matsui, K. Parallel findings in age-related macular degeneration and Alzheimer's disease. Prog. Retin. Eye Res. 2011, 30, 217-238. [CrossRef] [PubMed]

150. Anderson, D.H.; Talaga, K.C.; Rivest, A.J.; Barron, E.; Hageman, G.S.; Johnson, L.V. Characterization of $\beta$ amyloid assemblies in drusen: The deposits associated with aging and age-related macular degeneration. Exp. Eye Res. 2004, 78, 243-256. [CrossRef]

151. Johnson, L.V.; Leitner, W.P.; Rivest, A.J.; Staples, M.K.; Radeke, M.J.; Anderson, D.H. The Alzheimer's A-peptide is deposited at sites of complement activation in pathologic deposits associated with aging and age-related macular degeneration. Proc. Natl. Acad. Sci. USA 2002, 99, 11830-11835. [CrossRef]

152. Bevan, R.J.; Hughes, T.R.; Williams, P.A.; Good, M.A.; Morgan, B.P.; Morgan, J.E. Retinal ganglion cell degeneration correlates with hippocampal spine loss in experimental Alzheimer's disease. Acta Neuropathol. Commun. 2020, 8, 216. [CrossRef]

153. Bailey, S.T.; Thaware, O.; Wang, J.; Hagag, A.; Zhang, X.; Flaxel, C.J.; Lauer, A.K.; Hwang, T.S.; Lin, P.; Huang, D.; et al. Detection of Nonexudative Choroidal Neovascularization and Progression to Exudative Choroidal Neovascularization Using OCT Angiography. Ophthalmol. Retin. 2019, 3, 629-636. [CrossRef]

154. Sulzbacher, F.; Pollreisz, A.; Kaider, A.; Kickinger, S.; Sacu, S.; Schmidt-Erfurth, U.; the Vienna Eye Study Center. Identification and clinical role of choroidal neovascularization characteristics based on optical coherence tomography angiography. Acta Ophthalmol. 2017, 95, 414-420. [CrossRef]

155. Yu, J.-T.; Tan, L.; Hardy, J. Apolipoprotein E in Alzheimer's Disease: An Update. Annu. Rev. Neurosci. 2014, 37, 79-100. [CrossRef]

156. Baird, P.N.; Richardson, A.J.; Robman, L.D.; Dimitrov, P.N.; Tikellis, G.; McCarty, C.A.; Guymer, R.H. Apolipoprotein (APOE) gene is associated with progression of age-related macular degeneration (AMD). Hum. Mutat. 2006, 27, 337-342. [CrossRef]

157. Corder, E.H.; Saunders, A.M.; Strittmatter, W.J.; Schmechel, D.E.; Gaskell, P.C.; Small, G.W.; Roses, A.D.; Haines, J.L.; PericakVance, M.A. Gene dose of apolipoprotein E type 4 allele and the risk of Alzheimer's disease in late onset families. Science 1993, 261, 921-923. [CrossRef] [PubMed]

158. Chartier-Harlin, M.-C.; Parfitt, M.; Legrain, S.; Pérez-Tur, J.; Brousseau, T.; Evans, A.; Berr, C.; Vldal, O.; Roques, P.; Gourlet, V.; et al. Apolipoprotein E, $\varepsilon 4$ allele as a major risk factor for sporadic early and late-onset forms of Alzheimer's disease: Analysis of the 19q13.2 chromosomal region. Hum. Mol. Genet. 1994, 3, 569-574. [CrossRef]

159. Jiang, S.; Kametani, M.; Chen, D.F. Adaptive Immunity: New Aspects of Pathogenesis Underlying Neurodegeneration in Glaucoma and Optic Neuropathy. Front. Immunol. 2020, 11, 65. [CrossRef] [PubMed]

160. Lin, I.-C.; Wang, Y.-H.; Wang, T.-J.; Wang, I.-J.; Shen, Y.-D.; Chi, N.-F.; Chien, L.-N. Glaucoma, Alzheimer's Disease, and Parkinson's Disease: An 8-Year Population-Based Follow-Up Study. PLoS ONE 2014, 9, e108938. [CrossRef] [PubMed]

161. Bayer, A.U.; Ferrari, F.; Erb, C. High Occurrence Rate of Glaucoma among Patients with Alzheimer's Disease. Eur. Neurol. 2002, 47, 165-168. [CrossRef] [PubMed]

162. Sadun, A.A.; Bassi, C.J. Optic Nerve Damage in Alzheimer's Disease. Ophthalmology 1990, 97, 9-17. [CrossRef]

163. Ramirez, A.I.; de Hoz, R.; Salobrar-Garcia, E.; Salazar, J.J.; Rojas, B.; Ajoy, D.; López-Cuenca, I.; Rojas, P.; Triviño, A.; Ramírez, J.M. The Role of Microglia in Retinal Neurodegeneration: Alzheimer's Disease, Parkinson, and Glaucoma. Front. Aging Neurosci. 2017, 9, 214. [CrossRef]

164. Goldblum, D.; Kipfer-Kauer, A.; Sarra, G.-M.; Wolf, S.; Frueh, B.E. Distribution of Amyloid Precursor Protein and Amyloid- $\beta$ Immunoreactivity in DBA/2J Glaucomatous Mouse Retinas. Investig. Opthalmol. Vis. Sci. 2007, 48, 5085-5090. [CrossRef]

165. McKinnon, S.J. Glaucoma ocular Alzheimer s disease. Front. Biosci. 2003, 8, s1140-s1156. [CrossRef]

166. Chiasseu, M.; Vargas, J.L.C.; Destroismaisons, L.; Velde, C.V.; Leclerc, N.; Di Polo, A. Tau Accumulation, Altered Phosphorylation, and Missorting Promote Neurodegeneration in Glaucoma. J. Neurosci. 2016, 36, 5785-5798. [CrossRef]

167. Zabel, P.; Kaluzny, J.J.; Zabel, K.; Kaluzna, M.; Lamkowski, A.; Jaworski, D.; Makowski, J.; Gebska-Toloczko, M.; Kucharski, R. Quantitative assessment of retinal thickness and vessel density using optical coherence tomography angiography in patients with Alzheimer's disease and glaucoma. PLoS ONE 2021, 16, e0248284. [CrossRef] [PubMed]

168. Sommer, A. Intraocular Pressure and Glaucoma. Am. J. Ophthalmol. 1989, 107, 186-188. [CrossRef]

169. Kurna, S.A.; Akar, G.; Altun, A.; Agirman, Y.; Gozke, E.; Şengör, T. Confocal scanning laser tomography of the optic nerve head on the patients with Alzheimer's disease compared to glaucoma and control. Int. Ophthalmol. 2014, 34, 1203-1211. [CrossRef] [PubMed]

170. Hampel, H.; Toschi, N.; Babiloni, C.; Baldacci, F.; Black, K.L.; Bokde, A.L.; Bun, R.S.; Cacciola, F.; Cavedo, E.; Chiesa, P.A.; et al. Revolution of Alzheimer Precision Neurology. Passageway of Systems Biology and Neurophysiology1. J. Alzheimer's Dis. 2018, 64, S47-S105. [CrossRef] [PubMed]

171. Shi, Z.; Wu, Y.; Wang, M.; Cao, J.; Feng, W.; Cheng, Y.; Li, C.; Shen, Y. Greater Attenuation of Retinal Nerve Fiber Layer Thickness in Alzheimer's Disease Patients. J. Alzheimer's Dis. 2014, 40, 277-283. [CrossRef] 
172. Marziani, E.; Pomati, S.; Ramolfo, P.; Cigada, M.; Giani, A.; Mariani, C.; Staurenghi, G. Evaluation of Retinal Nerve Fiber Layer and Ganglion Cell Layer Thickness in Alzheimer's Disease Using Spectral-Domain Optical Coherence Tomography. Investig. Opthalmol. Vis. Sci. 2013, 54, 5953-5958. [CrossRef] [PubMed]

173. Pappuru, R.R.; Ouyang, Y.; Nittala, M.G.; Hemmati, H.D.; Keane, P.A.; Walsh, A.C.; Sadda, S.R. Relationship between Outer Retinal Thickness Substructures and Visual Acuity in Eyes with Dry Age-Related Macular Degeneration. Investig. Opthalmol. Vis. Sci. 2011, 52, 6743-6748. [CrossRef]

174. Gerth, C. The role of the ERG in the diagnosis and treatment of Age-Related Macular Degeneration. Doc. Ophthalmol. 2008, 118, 63-68. [CrossRef]

175. Lek, J.J.; Nguyen, B.N.; McKendrick, A.M.; Vingrys, A.J. An Electrophysiological Comparison of Contrast Response Functions in Younger and Older Adults, and Those With Glaucoma. Investig. Ophthalmol. Vis. Sci. 2019, 60, 442-450. [CrossRef] [PubMed]

176. Cordeiro, M.F.; Guo, L.; Coxon, K.M.; Duggan, J.; Nizari, S.; Normando, E.M.; Sensi, S.L.; Sillito, A.M.; Fitzke, F.W.; Salt, T.E.; et al. Imaging multiple phases of neurodegeneration: A novel approach to assessing cell death in vivo. Cell Death Dis. 2010,1 , e3. [CrossRef]

177. Dunaief, J.L.; Dentchev, T.; Ying, G.-S.; Milam, A.H. The Role of Apoptosis in Age-Related Macular Degeneration. Arch. Ophthalmol. 2002, 120, 1435-1442. [CrossRef]

178. Yap, T.E.; Donna, P.; Almonte, M.T.; Cordeiro, M.F. Real-Time Imaging of Retinal Ganglion Cell Apoptosis. Cells 2018, 7, 60. [CrossRef] [PubMed]

179. Dielemans, I.; Vingerling, J.R.; Algra, D.; Hofman, A.; Grobbee, D.E.; De Jong, P.T. Primary Open-angle Glaucoma, Intraocular Pressure, and Systemic Blood Pressure in the General Elderly Population. Ophthalmology 1995, 102, 54-60. [CrossRef]

180. Wang, J.J.; Foran, S.; Smith, W.; Mitchell, P. Risk of Age-Related Macular Degeneration in Eyes With Macular Drusen or Hyperpigmentation. Arch. Ophthalmol. 2003, 121, 658-663. [CrossRef]

181. Spaide, R.F.; Armstrong, D.; Browne, R. Choroidal neovascularization in age-related macular degeneration-What is the cause? Retina 2003, 23, 595-614. [CrossRef]

182. Kergoat, H.; Kergoat, M.-J.; Justino, L.; Chertkow, H.; Robillard, A.; Bergman, H. Visual Retinocortical Function in Dementia of the Alzheimer Type. Gerontology 2002, 48, 197-203. [CrossRef] [PubMed] 